\title{
Health Benefits and Pharmacological Properties of Hinokitiol
}

\author{
Naoufal El Hachlafi ${ }^{1}{ }^{(D}$, Fatima Lakhdar ${ }^{2}{ }^{D}$, Aya Khouchlaa ${ }^{3}$, Saad Bakrim ${ }^{4}$, Nasreddine El Omari ${ }^{5}$, \\ Abdelaali Balahbib ${ }^{6}$ (D), Mohammad Ali Shariati ${ }^{7}$ (D), Gokhan Zengin ${ }^{8}$ (D), Kawtar Fikri-Benbrahim ${ }^{1}$, \\ Giustino Orlando ${ }^{9}$, Claudio Ferrante ${ }^{9}$ (D), Luigi Meninghi ${ }^{9, *}$ (D) and Abdelhakim Bouyahya ${ }^{3, *(D)}$
}

1 Microbial Biotechnology and Bioactive Molecules Laboratory, Sciences and Technologies Faculty, Sidi Mohmed Ben Abdellah University, Fez B.P. 2626, Morocco; naoufal.elhachlafi@usmba.ac.ma (N.E.H.); kawtar.fikribenbrahim@usmba.ac.ma (K.F.-B.)

2 Laboratory of Marine Biotechnology and Environment, Department of Biology, Faculty of Sciences, Chouaib Doukkali University, El Jadida 24000, Morocco; fatimalakhdar24@gmail.com

3 Laboratory of Human Pathologies Biology, Department of Biology, Faculty of Sciences, Genomic Center of Human Pathologies, Mohammed V University, Rabat B.P. 1014, Morocco; aya.khouchlaa@gmail.com

4 Molecular Engineering, Valorization and Environment Team, Polydisciplinary Faculty of Taroudant, Ibn Zohr University, Agadir B.P. 32/S, Morocco; s.bakrim@hotmail.com

5 Laboratory of Histology, Embryology and Cytogenetic, Faculty of Medicine and Pharmacy, Mohammed V University, Rabat B.P. 9154, Morocco; nasrelomari@gmail.com

6 Laboratory of Biodiversity, Ecology and Genome, Faculty of Sciences, Mohammed V University, Rabat B.P. 1014, Morocco; balahbib.abdo@gmail.com

7 Departement of Technology of Food Production, K.G. Razumoysky Moscow State University of Technologies and Management, 109004 Moscow, Russia; shariatymohammadali@gmail.com

8 Biochemistry and Physiology Research Laboratory, Department of Biology, Faculty of Science, Selcuk University, 42130 Konya, Turkey; gokhanzengin@selcuk.edu.tr

check for

updates

Citation: El Hachlafi, N.; Lakhdar, F; Khouchlaa, A.; Bakrim, S.; El Omari,

N.; Balahbib, A.; Shariati, M.A.; Zengin, G.; Fikri-Benbrahim, K.; Orlando, G.; et al. Health Benefits and Pharmacological Properties of Hinokitiol. Processes 2021, 9, 1680. https://doi.org/10.3390/pr9091680

Academic Editor: Alina Pyka-Pajak

Received: 27 August 2021

Accepted: 16 September 2021

Published: 18 September 2021

Publisher's Note: MDPI stays neutral with regard to jurisdictional claims in published maps and institutional affiliations.

Copyright: (c) 2021 by the authors. Licensee MDPI, Basel, Switzerland. This article is an open access article distributed under the terms and conditions of the Creative Commons Attribution (CC BY) license (https:// creativecommons.org/licenses/by/ $4.0 /)$.
9 Department of Pharmacy, Botanic Garden "Giardino dei Semplici”, Università Degli Studi “Gabriele d'Annunzio", Via dei Vestini 31, 66100 Chieti, Italy; giustino.orlando@unich.it (G.O.); claudio.ferrante@unich.it (C.F.)

* Correspondence: luigi.menghini@unich.it (L.M.); boyahyaa-90@hotmail.fr (A.B.)

Abstract: Hinokitiol is a natural bioactive compound found in several aromatic and medicinal plants. It is a terpenoid synthetized and secreted by different species as secondary metabolites. This volatile compound was tested and explored for its different biological properties. In this review, we report the pharmacological properties of hinokitiol by focusing mainly on its anticancer mechanisms. Indeed, it can block cell transformation at different levels by its action on the cell cycle, apoptosis, autophagy via inhibiting gene expression and dysregulating cellular signaling pathways. Moreover, hinokitiol also exhibits other pharmacological properties, including antidiabetic, anti-inflammatory, and antimicrobial effects. It showed multiple and several effects through its inhibition, interaction and/or activation of the main cellular targets inducing these pathologies.

Keywords: hinokitiol; pharmacological action; cancer; NF-кB; signaling pathways

\section{Introduction}

Hinokitiol is a natural tropolone derivative compound and an essential oil component first identified in the heartwood of cupressaceous plants (Chamaecyparis taiwanensis) $[1,2]$. Hinokitiol is a $\beta$-thujaplicin chemically known as 2-hydroxy-4-isopropylcyclohepta-2,4,6trien-1-one, belonging to the class of monoterpenoids and has been considered to be a potent antimicrobial agent used in several industrial fields, including cosmetics, food, and some health care products, such as hair tonics, toothpaste, eyelid cleanser, hair restorers, skin soap, and body lotions [3-5].

This natural compound has shown numerous pharmacological properties, including antibacterial [6,7], antifungal [8], anti-inflammatory, anti-enzymatic [9,10], anticancer [11,12], antioxidant, neuroprotective [13], antidiabetic (Yamane), antiviral [14], antiplasmodial [15], and hepatoprotective effects [16]. Hinokitiol has demonstrated various anticancer activities 
against a wide variety of cell lines. Indeed, it has been shown to induce DNA damage and autophagy, leading to cell cycle alteration and senescence in lung adenocarcinoma cells. Moreover, hinokitiol has also caused apoptosis in the B16-F10 melanoma cell line by decreasing survivin protein expression and by upregulating extracellular signal-regulated kinase (ERK), mitogen-activated protein kinase phosphatase (MKP-3) pathways [2]. Furthermore, hinokitiol has also exhibited its anticancer properties by triggering other types of programmed cell death, such as paraptosis. Indeed, this monoterpene attenuated the $19 \mathrm{~S}$ proteasomal deubiquitinases (DUBs) by inducing paraptosis-like cell death mediated by transcription factor 4 (ATF4) and endoplasmic reticulum (ER) stress [17].

Recent investigations have demonstrated that hinokitiol inhibits cell growth, migration, and metastasis in breast cancer cell lines via downregulated heparanase expression by ERK and protein kinase B (AKT) signaling pathways [18]. On the other hand, hinokitiol has effective antimicrobial activities against both Gram-negative and Gram-positive antibiotic-resistant bacteria, including oral, nasal, and nasopharyngeal pathogenic bacteria $[6,7,9,19]$. In addition, this molecule has been shown to act as a promising antiinflammatory/immunomodulatory agent by inhibiting the production of some proinflammatory factors, such as tumor necrosis factor- $\alpha$ (TNF- $\alpha$ ), interleukin- 6 (IL-6), prostaglandin $\mathrm{E}_{2}$, nitric oxide (NO), and cyclooxygenase-2 (COX-2), by suppressing NF- $\mathrm{kB}$ activity in lipopolysaccharide (LPS)-stimulated cells via several mechanisms $[9,20,21]$.

The present review aims to critically highlight the comprehensive and current knowledge about the pharmacological properties of hinokitiol molecules, providing an overview of its mechanism of action evidenced by preclinical (in vitro and in vivo) and clinical investigations, and its potential use in drug discovery, especially for cancer therapy.

\section{Source of Hinokitiol}

Hinokitiol (Figure 1) is a naturally occurring tropolone compound, present in tropolone derivatives, first isolated in 1936 from Formosan cypress by Nozoe and collaborators (1936) [22]. Recently it has been reported from Thujopsis dolabrata, Chamaecyparis taiwanesis, plants belonging to Cupressaceae family $[23,24]$. After that, several hinokitiol-related compounds were isolated from Formosan cypress by Nozoe et al. (1951 and 1957), such as hinokitiol ( $\beta$-thujaplicin), $\beta$-dolabrin, $\alpha$-thujaplicin, and 4-acetyltropolone $[25,26]$.

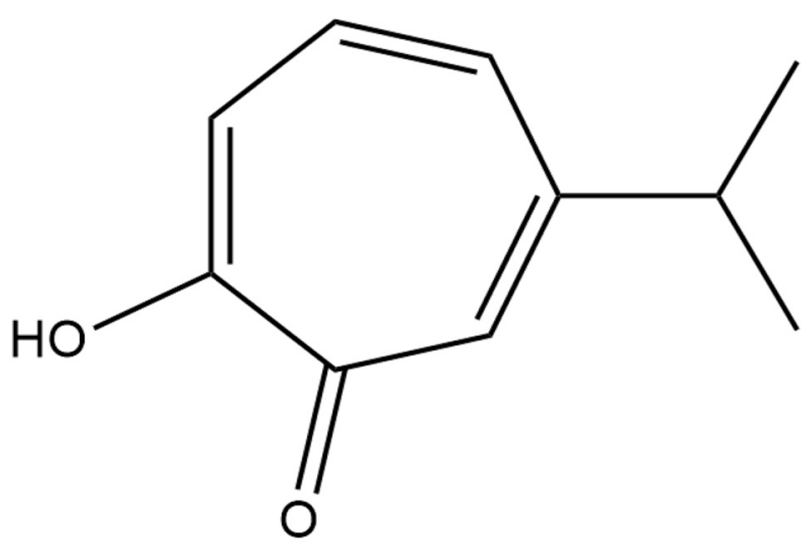

Figure 1. Chemical structure of hinokitiol.

\section{Pharmacological Properties of Hinokitiol}

\subsection{Antibacterial Effects and Mechanisms}

Hinokitiol has a wide antibacterial activity against a broad range of bacteria. However, its biosynthetic pathway and its biodegradation pathway remain unclear. Shih et al. [6] showed that the oral care products made of hinokitiol (isolated from Chamaecyparis taiwanensis) exhibit important antimicrobial activity [6]. The minimal inhibitory concentration (MIC) and minimal microbicidal concentration (MMC) of hinokitiol against MRSA (Methicillin-resistant S. aureus), Aggregatibacter actinomycetemcomitans, and Streptococcus 
mutans were determined using agar and broth dilution method (MIC: 40-110 $\mu \mathrm{M}$; MMC: 50-130 $\mu \mathrm{M})$. Using inhibition zone methods and kinetic microplate, a paradoxical inhibition phenomenon (PIP) was observed and confirmed in MRSA, A. actinomycetemcomitans and $S$. mutans. Indeed, it was shown that PIP positive is correlated with low autolysin activity. All the pathogens present an increase in cell diameter following hinokitiol treatment.

Suzuki et al. [27] showed that hinokitiol has polar groups allowing it to form metal complexes through coordinate bonds with metal ions. Increased antimicrobial activity was observed in hinokitiol, a metal ion (Cu (II)), and g-cyclodextrin (gCD) inclusion complex compared to hinokitiol alone. The level of antibacterial activity of an HT/gCD inclusion complex had action equivalent to that of a ternary complex. The MIC of HT alone was $80 \mathrm{mg} / \mathrm{mL}, 160 \mathrm{mg} / \mathrm{mL}, 80 \mathrm{mg} / \mathrm{mL}$, and $320 \mathrm{mg} / \mathrm{mL}$ for B. subtilis, S. aureus, E. coli, and P. aeruginosa, respectively. For the 1-hinokitiol-Cu, the MIC was $40 \mathrm{mg} / \mathrm{mL}$ for B. subtilis, $40 \mathrm{mg} / \mathrm{mL}$ for S. aureus, $80 \mathrm{mg} / \mathrm{mL}$ for E. coli, and $320 \mathrm{mg} / \mathrm{mL}$ for P. aeruginosa. However, the MIC of 2-hinokitiol-Cu was $20 \mathrm{mg} / \mathrm{mL}$ for B. subtilis, S. aureus, and E. coli, whereas for P. aeruginosa, the MIC was $160 \mathrm{mg} / \mathrm{mL}$.

Hinokitiol was integrated into the poly [(R)-3-hydroxybutyrate-co-(R)-3hydroxyhexanoate] $(\mathrm{PHBH})$ polymer as a natural antibacterial reagent using an electrospinning process to produce antibacterial wound dressings. The results showed that the addition of ethanol-hinokitiol $(\mathrm{EH})$ at various ratios has an influence on the surface morphology of $\mathrm{PHBH}$ composite nanofibers and the fiber diameters compared to pristine PHBH nanofibers. Additionally, potent inhibitors against the growth of Staphylococcus aureus and Escherichia coli were demonstrated in $\mathrm{PHBH}$ composite nanofibers containing hinokitiol products. PHBH/30EH (1\%) composite nanofibers have shown an extensive inhibition zone with $25.7 \mathrm{~mm}$ against $S$. aureus and $29.7 \mathrm{~mm}$ against E. coli [28].

A broad spectrum of pathogenic oral, nasal, and nasopharyngeal bacteria was treated by hinokitiol, which exhibits important antibacterial activity against Aggregatibacter actinomycetemcomitans, Streptococcus mutans, methicillin-resistant, and susceptible Staphylococcus aureus, Porphyromonas gingivalis, Streptococcus sobrinus, Prevotella intermedia, antibioticresistant, and susceptible Streptococcus pneumoniae and Streptococcus pyogenes and Fusobacterium nucleatum. Indeed, hinokitiol significantly inhibited the growth of all these bacterial strains with a minimal inhibitory concentration ranging between 0.3 and $50 \mu \mathrm{g} / \mathrm{mL}$ [7].

Therefore, the aerobic and anaerobic oral bacterial numbers in the silk ligatures tied around the maxillary second molars decreased both when injecting hinokitiol [19].

Hinokitiol has already been reported to show important antimicrobial activity against a broad spectrum of pathogenic bacteria with a range between 0.1 and $164 \mu \mathrm{g} / \mathrm{mL}$. Strong activity against Staphylococcus epidermidis was found, with MIC of $0.16 \mu \mathrm{g} / \mathrm{mL}$ [29].

Oral tissue reconstruction and facial surgery to isolate connective and epithelial tissues often use hydrogel membranes as physical barriers and form a closed space for undisturbed bone healing. The regeneration of membranes made of gelatin and hyaluronic acid, crosslinked with genipin and loaded with a hinokitiol additive, were used as a bacteriostatic agent for potential applications at a concentration of up to $0.16 \mathrm{~g} / \mathrm{L}$. Antibacterial activity and biocompatibility on each membrane side were shown in this bifunctional membrane for proper biodegradation. The larger zones of microbial inhibitions were observed in the RM-4H group highly charged with hinokitiol against $S$. aureus and E. coli. Compared with the control group, the inhibitory effect on E. coli growth was more important than that on S. aureus growth as the amount of hinokitiol loading increased [30]. Indeed, the hydrogel regeneration membranes crosslinking by N-(3-dimethylaminopropyl)- $\mathrm{N}^{\prime}$ ethylcarbodiimide hydrochloride had the largest inhibition area against S. aureus and E. coli when it is impregnated with a high concentration of hinokitiol [31].

It has been shown that $50 \%$ and $60 \%$ of E. faecalis growth was inhibited after $3 \mathrm{~h}$ and 6 $\mathrm{h}$, respectively, with calcium silicate cements containing 1 and $10 \mathrm{mM}$ hinokitiol [32].

Inoue et al. [33] showed that the hinokitiol irreversibly inhibits in a short amount of time the growth of microorganisms. The antimicrobial activity of hinokitiol was retained as a result of including hinokitiol in a cyclodextrin complex. 
Hinokitiol alone showed MIC of $80 \mu \mathrm{g} / \mathrm{mL}$ against B. subtilis, $160 \mu \mathrm{g} / \mathrm{mL}$ for $S$. aureus, $80 \mu \mathrm{g} / \mathrm{mL}$ for E. coli, and $320 \mu \mathrm{g} / \mathrm{mL}$ against $P$. aeruginosa.

However, the hinokitiol/cyclodextrin complexes had MICs of $160 \mu \mathrm{g} / \mathrm{mL}$ against $P$. aeruginosa, $40 \mu \mathrm{g} / \mathrm{mL}$ with respect to $S$. aureus, and $20 \mu \mathrm{g} / \mathrm{mL}$ against $B$. subtilis and E. coli. The antimicrobial activity of hinokitiol alone was lesser than that of complexes, which increased about fourfold.

Strong antibacterial properties were shown in both hinokitiol and the hinokitiol/organic acid mixture combination on Gram-positive bacteria, such as S. bovis. S. bovis growth was inhibited using hinokitiol greater than $1.56 \mathrm{mg} / \mathrm{mL}$ or the organic acid mixture greater than $1600 \mathrm{mg} / \mathrm{mL}$. S. bovis was also inhibited with the combination of $0.78 \mathrm{mg} / \mathrm{mL}$ hinokitiol and $200 \mathrm{mg} / \mathrm{mL}$ of the organic acid mixture, demonstrating that the combination was more effective at a lower concentration in combination than when used separately. MICs of hinokitiol were $0.39-1.56 \mathrm{mg} / \mathrm{mL}$ for the Gram-positive S. bovis, Lactobacillus ruminis, and B. ruminantium, and $25 \mathrm{mg} / \mathrm{mL}$ for Gram-negative Megasphaera elsdenii. In contrast, Gram-positive bacteria were inhibited more strongly than Gram-negative using hinokitiol and organic acid mixture combination or hinokitiol as a sole additive [34].

Although the mechanisms involved in the bactericidal effects of hinokitiol are not fully understood, nevertheless, the mechanism of antibacterial activity of hinokitiol is the result of inhibition of metabolism in the bacterial cell membrane in connection with respiration and membrane permeability. Its bactericidal mechanisms could be similar to those of other phenolic compounds [35]. Likewise, hinokitiol inhibits the respiration of cells of both bacteria. Indeed, it showed not only bactericidal activity but also oxygen consumption inhibition against bacteria. Zeighampour et al. [36] explained that the different cell wall chemical structures of bacteria have an influence on the difference in antibacterial activity observed between Gram - and Gram + bacteria. Morita et al. [37] demonstrated that in both E. coli and S. aureus, hinokitiol inhibits the respiration of cells and transport of nutritious substrates without leakage of proteins or nucleic acids or morphological change. They also reported that a higher concentration of hinokitiol is required to eliminate E. coli than to eliminate $S$. aureus. In this regard, the differences in the structures of bacterial cell membranes explain the differences in antibacterial activities of hinokitiol observed against Gram-positive and Gram-negative bacteria [38].

\subsection{Antifungal Effects and Mechanisms}

Hinokitiol was also evaluated for its antifungal activities against the fungal species Saprolegnia, Aphanomyces and Achlya. Hinokitiol showed strong antifungal activity against all the examined fungal isolates. The minimum inhibitory concentration (MIC) values being $12.5 \mu \mathrm{g} / \mathrm{mL}$. The concentration of $100 \mu \mathrm{g} / \mathrm{mL}$ of hinokitiol was the most effective to inhibit the hyphal growth of $S$. parasitica and Aphanomyces spp. but not of S. diclina and Achlya. In addition, hinokitiol exhibited fungicidal activity against zoospores germination of Saprolegnia spp. at $100 \mu \mathrm{g} / \mathrm{mL}$, whereas of Aphanomyces spp. at 12.5-25 $\mu \mathrm{g} / \mathrm{mL}$ [39].

Saniewska and Saniewski [40] showed that hinokitiol was able to strongly inhibit the mycelium growth of the fungi Phoma narcissi, head of Hippeastrum, and other species of Amaryllidaceae family. The antifungal activity was evaluated in vitro on a PDA medium. After 7 days of incubation, the mycelium growth of Phoma narcissi was limited by 50.5, 61.5 , and $88.4 \%$ when hinokitiol was applied at a concentration of 10,15 , and $25 \mu \mathrm{g} \cdot \mathrm{cm}^{-3}$, respectively. However, at concentrations of $50.0 \mu \mathrm{g} \cdot \mathrm{cm}^{3}$, the inhibition was significantly higher. Total inhibition of the mycelium growth of Phoma narcissi was obtained. They concluded that the hinokitiol at a concentration of $100.0 \mu \mathrm{g} \cdot \mathrm{cm}^{-3}$ had fungicidal activity.

In their study, Komaki et al. [41] demonstrated that the growth of the cells was dosedependently inhibited by the addition of hinokitiol. The findings indicated that the MIC of hinokitiol against C. albicans NIH A-207 was $5 \mathrm{mg} / \mathrm{mL}$. The MIC of hinokitiol against several C. albicans strains were similar to that of C. albicans NIH A-207, indicating that hinokitiol exhibited antifungal activity against C. albicans strains [41]. 
Saniewska and Jarecka, [42] investigated the antifungal activity of hinokitiol against F. oxysporum f. sp. tulipae. The quantitative antifungal assay of hinokitiol was carried out on potato dextrose agar (PDA). In the study, they documented the test concentrations of hinokitiol that showed total inhibition of the mycelium growth were $50.0 \mathrm{~g} / \mathrm{cm}^{3}$. Moreover, the isolate F.ox.t. 218 was more affected by hinokitiol than isolate F.ox.t. 17.

Hu et al. [43] revealed that hinokitiol-potassium salt showed antifungal activity against a broad spectrum of pathogen fungi, and its antifungal activity on the fungi examined (A. niger, P. citrinum, T. viride) was stronger than that of the carbendazim, which was used as a positive control. At a concentration of $30 \mathrm{mg} / \mathrm{L}$, HK-K salt presented good efficacy, and $50 \mathrm{mg} / \mathrm{L}$ of $\mathrm{HK}-\mathrm{K}$ salt produced great antimold activity; the killed value is between 0 and 1.

Recently, Wang et al. [8] attempted to identify the antifungal effect of hinokitiol against B. cinerea both in vitro and in vivo. Hinokitiol was able to control the fungus by reducing mycelial growth, the incidence and severity of the disease; in addition, some genes linked to the pathogenicity of the fungus were reduced. The in vitro activity of hinokitiol for $72 \mathrm{~h}$ showed that there was complete inhibition of $B$. cinerea with $40 \mathrm{mg} / \mathrm{L}$, whereas with $20 \mathrm{mg} / \mathrm{L}$, the germination of the spores was completely deleted. At present, Jin et al. [44] documented that hinokitiol exhibits potential antifungal activity against a panel of Candida strains with multiple azole-resistant mechanisms and persistently inhibited Candida albicans growth with MIC values of $0.5-2 \mu \mathrm{g} / \mathrm{mL}$.

It is well known that hinokitiol has potent antifungal activity against a range of plants pathogens. However, the mechanism of antimicrobial activity of hinokitiol is unknown [45]. Nevertheless, in their study, Jin et al. [44] also explored the antifungal mechanisms of hinokitiol against Candida albicans. Accordingly, hinokitiol inhibited the respiration of fungal cells. Moreover, the results indicated that it inhibited the activities of mitochondrial respiratory chain complexes I and II and reduced mitochondrial membrane potential by decreasing intracellular ATP synthesis and increasing detrimental intracellular reductive stress.

\subsection{Antiviral Effects and Mechanisms}

Hinokitiol is considered a safe zinc ionophore that increases intracellular zinc levels considerably, especially in the endosomal-lysosomal section [46].

It has been shown that viral replication is inhibited by hinokitiol by impairing viral polyprotein processing; however, this ability is determined by the availability of zinc ions. Thus, a rise in intracellular zinc levels provides the grounding for a new antipicornavirus mechanism [14].

Krenn et al. [14] demonstrated that a rapid import of extracellular zinc into the cytoplasm was caused by the metal ion binding compounds, such as hinokitiol. Basically, the human coxsackievirus, rhinovirus, and mengovirus multiplication were inhibited efficiently by hinokitiol treatment. They related the increased intracellular $\mathrm{Zn}^{2+}$ levels and the ability to chelate $\mathrm{Zn}^{2+}$ ions with the effectivity of hinokitiol against human mengovirus, rhinovirus, and coxsackievirus

Likewise, other in vitro studies showed the inhibition of the replication of several RNA viruses, including respiratory syncytial virus, influenza virus and various picornaviruses involving added $\mathrm{Zn}^{2+}$ in the presence of hinokitiol (HK) $[47,48]$.

\subsection{Antiparasitic Effects}

The list of antiplasmodial phytochemicals isolated from medicinal plants is very short [49]. The in vitro activity of hinokitiol against Plasmodium falciparum was assessed from the study performed by Fujisaki et al. [15]. They revealed that hinokitiol was shown to be effective against $P$. falciparum with an $\mathrm{IC}_{50}$ value equal to $1.0 \mu \mathrm{g} / \mathrm{mL}$. Additionally, in the same study, hinokitiol also had potent antiplasmodium activity in vivo. On the 9th day, the parasitemia decreased to $5.6 \%$ versus $28.7 \%$ for the negative control after treatment with feneous oil associated with $10 \%$ hinokitiol at a dose of $385 \mathrm{mg} / \mathrm{kg}$ three 
times a day for three days. The mechanisms involved in this activity are not clearly defined. Nevertheless, it appears that the antiplasmodial action of hinokitiol is timedependent. Hinokitiol was shown to be more active when the half-life was relatively long after percutaneous administration to a mouse model infected by Plasmodium berghei NK-5. On another point, P. falciparum relies primarily on glycolysis for energy production, involving the $P$. falciparum glyoxalase I monomer ( $p f \mathrm{GLOI})$. The in vitro study by Barnard et al. [50] reported that there is a correlation between antimalarial activity and yeast glyoxalase I ( $y$ GLOI) inhibitory activity due to the presence of a free C-2 hydroxyl for both properties. Similarly, in the experiment performed by Ishiyama et al. [51], at low substrate concentration $(5 \mu \mathrm{M})$, hinokitiol had free C-2 hydroxyl and showed a highly effective inhibitory activity against $p f \mathrm{GLOI}$ with an $\mathrm{IC}_{50}$ value of $3.48 \pm 1.41 \mu \mathrm{M}$. Therefore, it revealed an antimalarial activity against $P$. falciparum $\mathrm{K} 1$ strain with an $\mathrm{IC}_{50}=29.96 \mu \mathrm{M}$. Based on these findings, the authors supported the hypothesis that the antimalarial mode of action of hinokitiol could be through the inhibition of $p f$ GLOI.

In a Japanese study, Chisty and colleagues [52] investigated the effect of hinokitiol on Schistosoma mansoni cercariae in vitro. Examination of cercariae by transmission electron microscopy showed that hinokitiol causes structural changes at a concentration of $50 \mu \mathrm{g} / \mathrm{mL}$, which may explain the inability of hinokitiol-treated cercariae to infect the host.

A study by Rivas et al. [53] focused its interest on parasitic diseases, in particular Chagas disease, caused by Trypanosoma brucei parasites; the use of ferrocenyl heterobimetallic compounds with tropolones (or hinokitiol) can be a promising strategy. The compounds exhibited good potentials in the bloodstream of T. brucei. The probable mechanism of action of the antiparasitic effect of these compounds could not be attributed to the potential interference of the compounds with the thiol-redox homeostasis of the pathogen, but DNA may be a prospective target depending on the fluorescence measurement.

\subsection{Antioxidant Effects and Mechanisms}

It has been shown that hinokitiol at a high dose is one pro-oxidant and can increase the GSH-Px, SOD, and CAT activities as well as decrease the malondialdehyde (MDA) level in ducklings [54]. Obviously, after the treatment of hinokitiol, the anti-oxidative effect of baicalin phospholipid complex (BAPC) was neutralized. Under the treatment of hinokitiol, GSH-Px, SOD, and CAT activities decreased significantly in the serum and liver. And in the meantime, both in the serum or liver, the amounts of MDA increased significantly. This indicated the pro-oxidative effect of hinokitiol. Though hinokitiol intervened, the antioxidative effect of BAPC did not affect the curative effect of BAPC on ducklings infected by DHAV-1 [55].

Chen et al. [54] have shown that hinokitiol exhibited different effects on the oxidative evaluation indexes, using a two-day-old duckling model. Hinokitiol at $20 \mathrm{mg} / \mathrm{kg}$ significantly decreased the MDA value; at $40 \mathrm{mg} / \mathrm{kg}$ significantly increased the CAT value; at 80 and $100 \mathrm{mg} / \mathrm{kg}$ significantly increased the MDA value while decreased the values of SOD, GSH-Px, and CAT. However, the anti-oxidative or pro-oxidative effect depended on the dosage of hinokitiol. Hinokitiol wiped off the anti-oxidative abilities of BSRPS and sBSRPS after being treated with the dose of $80 \mathrm{mg} / \mathrm{kg}$ for three days; all the per-oxidative degrees of the ducklings were significantly higher $(p<0.05)$ than those of the corresponding untreated ducklings. These higher degrees carried over into the 54th hour after the toxicity attacking [54].

It has been shown that hinokitiol definitely inhibited the browning of apple sections. They competitively inhibited apple polyphenol oxidase (PPO). An apple section sprayed with a $0.02 \%$ hinokitiol solution did not turn brown for $2 \mathrm{~h}$ at room temperature. The Ki value of hinokitiol against apple PPO was $5.5 \mu \mathrm{M}$, while the $\mathrm{Km}$ value of chlorogenic acid was $2.5 \mathrm{mM}$. Furthermore, hinokitiol non-competitively inhibited tyrosinase and the discoloration of shrimp caused by tyrosinase during cold storage [56]. 


\subsection{Antidiabetic Effect}

Few studies have investigated the antidiabetic effect of hinokitiol [57,58]. A study conducted by Yamane and coworkers [57] evaluated the effect of di(hinokitiolato)zinc complex $\left(\mathrm{Zn}(\mathrm{hkt})_{2}\right)$ on type 2 diabetic KK-A $\mathrm{A}^{\mathrm{y}}$ mice. At a dose of $2 \mathrm{mg} \mathrm{Zn/kg}$ body weight, $\mathrm{Zn}(\mathrm{hkt})_{2}$ exhibited a remarkable normoglycemic effect after 2-3 days of treatment and during the 14-day administration period. $\mathrm{Zn}(\mathrm{hkt})_{2}$ reduced the blood glucose levels in untreated type 2 diabetic KK-A $\mathrm{A}^{\mathrm{y}}$ mice ( $370 \pm 53$ and $485 \pm 66 \mathrm{mg} / \mathrm{dL}$ h, respectively). Concomitantly, GOT, GPT, and UN levels, indicators of hepatotoxicity and nephrotoxicity development, were not affected (146 vs. $116 \mathrm{U} / \mathrm{L}, 32$ vs. $33 \mathrm{U} / \mathrm{L}$, and 25 vs. $35 \mathrm{mg} / \mathrm{dL}$, respectively). Naito et al. [58] investigated in vitro the cellular mechanism of $\mathrm{Zn}(\mathrm{hkt})_{2}$ complexes in diabetes mellitus (DM) by studying the activation of the insulin signaling pathway in 3T3-L1 adipocytes. At $50 \mu \mathrm{M}, \mathrm{Zn}(\mathrm{hkt})_{2}$ stimulated insulin signaling pathways by strongly inducing Akt/protein kinase B (Akt/PKB) phosphorylation and phosphorylation of glycogen synthase kinase-3 $\beta$ (GSK3 $\beta$ ), a key enzyme involved in glycogen metabolism. Using an atomic absorption spectrophotometer, Zn uptake in 3T3-L1 adipocytes was measured. After treatment with $50 \mu \mathrm{M}$ of $\mathrm{Zn}(\mathrm{hkt})_{2}$, the intracellular $\mathrm{Zn}$ concentration was higher $(77.2 \mathrm{ng} / \mathrm{mL})$ than that of the control cells $(15.2 \mathrm{ng} / \mathrm{mL}$ using DMSO). Additionally, the glucose uptake of $\mathrm{Zn}(\mathrm{hnk})_{2}$-treated adipocytes was 3.7-fold higher than that of the control adipocytes. From this study, the authors suggested that GLUT4 translocated to the plasma membrane, which increased glucose uptake level [58]. Thus, hinokitiol can be a promoter compound used to treat DM. However, further preclinical tests (in vivo activities, and pharmacokinetic and pharmacodynamic effects) should be conducted to evaluate the safety and efficacy of this compound.

\subsection{Anti-Inflammatory Effect}

Several in vitro research have evaluated the anti-inflammatory effect of hinokitiol. The analgesic effect of hinokitiol was evaluated by RT-PCR with the main aim to cure hair loss by removing the factors that promote follicular apoptosis [59]. Byeon et al. [59] evaluated the effect of hinokitiol on TNF- $\alpha$ production in lipopolysaccharide (LPS)-activated macrophage (RAW264.7) cells. The result indicated significant suppression of TNF- $\alpha$ production in a dose-dependent manner $\left(\mathrm{IC}_{50}=212 \mu \mathrm{M}\right)$ compared to pentoxifylline and theophylline $\left(\mathrm{IC}_{50}=228 \mu \mathrm{M}\right.$ and $\mathrm{IC}_{50}=452 \mu \mathrm{M}$, respectively). Moreover, at $200 \mu \mathrm{M}$, hinokitiol suppressed inducible nitric oxide (NO) synthase transcription and NO production. In addition, it suppressed TNF- $\alpha$ mRNA synthesis under LPS exposure and downregulated the phosphorylation of PDK1, Akt/PKB, and extracellular signal-regulated kinase (ERK), resulting in a loss of nuclear factor (NF)- $\mathrm{KB}$ activation. Li et al. [60] investigated in vitro the anti-inflammatory effect of hinokitiol at different concentrations $(10-80 \mu \mathrm{M})$ on matrix metalloproteinase (MMP)-1, $-3,-13$, type II collagen gene (Col2a1) and $\beta$-catenin in cultured chondrocytes. Using the MTT assay, no significant cytotoxicity of hinokitiol against normal chondrocytes was observed. At the same time, significant inhibition of interleukin (IL)-1 $\beta$ stimulated MMP-1,-3, and -13 expressions was observed in a dose-dependent manner using hinokitiol compared to IL-1 $\beta$ alone. In addition, hinokitiol downregulated the MMP-1, -3, -13 , and $\beta$-catenin protein levels, whereas the relative expression of Col2a1 was increased. From this research, the authors suggested that hinokitiol has an anti-inflammatory effect by inhibiting the Wnt $/ \beta$-catenin signaling pathway [60]. Shih et al. [61] evaluated in vitro the effect of dental root canal sealers (Apexit Plus (AP), calcium-hydroxide-based) with hinokitiol on the inflammation genes cyclooxygenase-2 (COX-2), hypoxia-inducible factor1a (HIF-1a), and lysyl oxidase (LOX) mRNA expression in human osteosarcoma cell lines (MG-63) and human gingival fibroblasts (HGF) cells. COX-2 expression was downregulated by AP $+(0.5-1 \%)$ hinokitiol and AP $+1 \%$ hinokitiol in MG-63 and HGF, respectively, while HIF- $1 \alpha$ expression was downregulated in MG-63 and HGF. LOX expression did not differ significantly in MG-63 after AP + (0.5-1\%) hinokitiol conditional medium incubation but was inhibited in HGF after AP $+1 \%$ hinokitiol treatment [61]. The anti-inflammatory effect of hinokitiol $(0,25,50$, and $100 \mu \mathrm{M})$ in human corneal epithelial (HCE) cells was 
investigated by Ye et al. (2015). At $100 \mu \mathrm{M}$, hinokitiol significantly decreased the mRNA levels of IL-8, IL-6, and IL-1 $\beta$ to $58.77 \%, 64.64 \%$, and $54.19 \%$, respectively, compared to cells stimulated with poly(I:C) alone. Furthermore, NF- $\mathrm{kB}$ p65 subunit translocation to the nucleus has been reduced by hinokitiol, which significantly inhibited the activation of the NF-kB signal pathway. Ye et al. (2015) suggested that hinokitiol had an anti-inflammatory effect by inhibiting the NF-KB pathway [10]. In 2016, Huang and coworkers [32] assessed the effect of hinokitiol at different concentrations $(0-10 \mathrm{mM})$ on the production of COX-2 and IL-1 $\beta$ in LPS-treated human dental pulp cells (hDPCs) directly cultured on calcium silicate (CS) cements. They found a significant anti-inflammation ability of this molecule at different concentrations $(0-10 \mathrm{mM})$ in the inhibition of COX-2 and IL- $1 \beta$ expression induced by LPS in hDPCs. The anti-inflammatory potential of hinokitiol at different concentrations $(2.5,5,10,20$, and $40 \mu \mathrm{mol} / \mathrm{L})$ was investigated in normal human epidermal keratinocyte (NHEK) cells exposed to LPS [9]. The results showed an attenuation of TNF- $\alpha$, IL-6, and prostaglandin $\mathrm{E}_{2}\left(\mathrm{PGE}_{2}\right)$ release induced by hinokitiol. Moreover, this monoterpenoid decreased the levels of nuclear NF- $\mathrm{kB}$ p65 protein, using Western blot analysis, and reduced LPS-induced MMP-9 activity in NHEK cells, using gelatin zymography. The authors confirmed that these effects were mediated by Sirt1, a histone deacetylase known to suppress oxidative stress and inflammation $[62,63]$. The in vitro anti-inflammatory effect of hinokitiol was evaluated by Hyoshi et al. [19], as well. They studied the gene transcription profile in LPS-treated RAW264.7 cells in the presence of hinokitiol at different concentrations $(5-20 \mu \mathrm{g} / \mathrm{mL})$. The treatment with hinokitiol significantly decreased the mRNA levels of IL-6, IL1 $\beta$, and TNF $\alpha$ genes without affecting cell viability, while the transcription of the Nlrp3 gene was not affected by this treatment.

The anti-inflammatory activity of hinokitiol has also been evaluated using animal models. The in vivo anti-inflammatory effect of hinokitiol was investigated by Hiyoshi et al. [19] concerning periodontal bone loss in a murine model of periodontitis. They found that hinokitiol $(2 \mathrm{mg} / \mathrm{mL})$, injected for 7 days into the palatal gingiva, inhibited the transcription levels of inflammatory cytokine-related genes, and Nlrp3 in the gingiva of mice with ligature-induced periodontitis.

\subsection{Hepatoprotective Effect}

The protective effect of hinokitiol against liver injury was first evaluated in in vivo assays. Lu and coworkers [16] investigated the role of hinokitiol following hemorrhagic shock and resuscitation (HS/R). They revealed that hinokitiol pretreatment $(1.7 \mathrm{mg} / \mathrm{kg}$, intravenous) decreased serum ALT, AST, and LDH levels and markedly reduced p65 phosphorylation and increased IкB $\alpha$ degradation. Thus, hinokitiol markedly attenuated HS/R-induced hepatic injury and improved liver injury via inhibition of NF- $\kappa$ B activation [16].

\subsection{Neuroprotection Effects}

Hinokitiol may offer a powerful neuroprotective activity; the in vivo study performed by Jayakumar et al. [64] showed that the expression of middle cerebral artery occlusion (MCAO)-induced thromboembolic stroke in rats was alleviated after intraperitoneal treatment with hinokitiol through the enhancement in neurobehavior and reduction in infarct size in rats with brain damage (ischemia) [64]. The mechanisms involved in the treatment of this neurological deficit were downregulation of inflammatory protein expression, such as TNF- $\alpha$, HIF $1 \alpha$, inducible nitric oxide synthase (iNOS), and active caspase- 3 by hinokitiol $(0.2$ and $0.5 \mathrm{mg} / \mathrm{kg})$ administration. Indeed, hinokitiol showed anti-thrombogenic activity and antiplatelet activity. Moreover, the study by Varier and Sumathi, [65] demonstrated that in Parkinson's disease, hinokitiol may play a key role against 6-OHDA-induced toxicity in SH-SY5Y neuroblastoma cells via a decrease in the mRNA expression of several proteins implicated in this disorder, including $\alpha$-synuclein, monoamine oxidases (MAO-A), MAO-B, PTEN-induced putative kinase 1 (PINK1), phosphate and tensin homolog (PTEN), leucine-rich repeat kinase 2 (LRRK2), and PARK7 (deglycase 1 (DJ-1)). On the other hand, 
in prion disease, Moon et al. [66] reported that hinokitiol could be a drug of choice in the treatment of this neurodegenerative disorder. Indeed, this bioactive plant can lead to a beneficial effect against prion peptide (106-126)-induced neurotoxicity by enhancing the expression of autophagy markers, such as protein light chain 3 (LC3-II) and green fluorescence protein (GFP)-LC3 puncta, through the HIF1 $\alpha$ pathway. Furthermore, iron overload can damage brain functions and affect neurotransmitter synthesis. Hinokitiol was found to play a neuroprotective role by chelating iron and was revealed to be more effective than chelation therapies, such as desferrioxamine (DFO) and deferiprone (L1) [67]. With the aim of evaluating the in vitro effect of natural $\beta$-thujaplicin and its substituted synthetic derivatives in the protection of neuronal cells against cellular damage induced by oxidative stress, the work of Koufaki et al. [13] showed that only piperazine as a new antioxidant compound derived from $\beta$-thujaplicin was found to be more active (with an $\mathrm{EC}_{50}$ of 0.08 to $1.7 \mathrm{mM}$ ) than the natural molecule $\beta$-thujaplicin, in preventing HT22 hippocampal neurons against oxytosis.

\subsection{Antiperiodontal Bone}

Periodontitis, also called gum disease or periodontal disease, is an infectious disease caused by dysbiotic oral microflora that gradually triggers bone resorption and results in tooth loss [68]. This infection causes an inflammatory process due to the presence of a complex group of Gram-negative bacteria that leads to the release of proinflammatory mediators [69]. Hiyoshi et al. [19] investigated the impact of hinokitiol on induced periodontitis in mice and its inflammatory action. The results of this experiment confirmed that hinokitiol treatment causes a significant improvement in the signs of periodontitis due to its antibacterial and anti-inflammatory action. Indeed, this medicinal compound has revealed anti-inflammatory characteristics, notably a decrease in the mRNA transcription levels from LPS-induced proinflammatory cytokine-linked genes in RAW264.7 cells and also the suppression of NLRP3 inflammasome in the gingiva of animals. The NLRP3 pathway provokes caspase- 1 activation and the release of proinflammatory mediators in response to microbial infection [70]. Additionally, Domon et al. [7] reported the antibacterial activity of hinokitiol against a wide range of oral pathogen bacteria that induce periodontitis, including Prevotella intermedia, Porphyromonas gingivalis, Streptococcus mutans, Aggregatibacter actinomycetemcomitans, and Fusobacterium nucleatum. These findings showed that this natural compound may be a potent candidate in the treatment of periodontal bone loss, but further investigations are needed to elucidate the mechanisms involved in this pathogenesis.

\subsection{Thrombus Inhibition and Antityrosinase Effect}

\subsubsection{Thrombus Inhibition}

Platelets and protein coagulation factors are two interdependent mechanisms that lead to thrombus formation [71,72]. The aggregation of platelets with others and the release of platelet agonists and procoagulants are induced by the activation of platelets which undergo spectacular changes in their shape [71], leading to the activation of blood coagulation by intrinsic and extrinsic pathways [72]. Hinokitiol may be a promising therapeutic agent for the prevention or management of thrombotic events. The ex vivo study performed by Lin et al. [20] demonstrated that the use of hinokitiol (1 and $2 \mathrm{mM})$ in this experiment induced platelet inactivation by suppressing the phosphorylation of phospholipase $\mathrm{C}$ (PLC) $\gamma 2$ and/or protein kinase C (PKC) pathways and hydroxyl radical $\left(\mathrm{OH}^{-}\right)$formation, and subsequently caused the inhibition of mitogen-activated protein kinases (MAPKs) and Akt/Protein kinase B (PKB) activation. The succession of these physiological events promotes the downregulation of the intracellular $\mathrm{Ca}^{2+}$ level. Therefore, collagen-induced platelet aggregation will be inhibited. Furthermore, hinokitiol has inhibitory activity on thrombogenesis in mice models. However, it had no effect on platelet inactivation via other agonists, such as arachidonic acid, thrombin, and adenosine diphosphate (ADP). 
In parallel, in another experimental study by Lu et al. (2014), they noticed that convulxin-mediated activation routes of PLC $\gamma 2$, PKC, Akt, MAPK, and Lyn were blocked under the action of hinokitiol. Furthermore, it was found by the authors that hinokitiol caused an inhibition of platelet aggregation and $\mathrm{Ca}^{2+}$ mobilization promoted by GP VI, an agonist of convulxin, but not by the $\alpha 2 \beta 1$ integrin, an agonist of aggreterin. They also observed that hinokitiol blocked convulsin-induced phosphorylation of PLC $\gamma 2$ and p47. Indeed, the stimulation of platelets by convulsin or collagen results in PLC $\gamma 2$-catalyzed hydrolysis of phosphatidylinositol 4,5-bisphosphate (PIP2) and simultaneous formation of inositol 1,4,5-trisphosphate (IP3) and -diacylglycerol (DAG). As follows, DAG also stimulates $\mathrm{PKC}$, inducing phosphorylation of $\mathrm{p} 47$. These findings concluded that hinokitiol is a potent GP VI antagonist on the platelet membrane, thereby inhibiting platelet activation and preventing thrombus formation [73].

On the other hand, in the context of uncontrolled management of hemorrhagic shock, fluid resuscitation is required to avoid organ dysfunction and tissue hypoxia. Indeed, this fluid resuscitation may lead to an intensification of coagulopathy and inflammation, which can lead to a dilution of the coagulation factors and a reinforced leukocyte-endothelium interaction. Due to its antiplatelet and anti-inflammatory activity, the in vivo experiments conducted by Lu et al. [16] showed that hinokitiol significantly alleviated hemorrhagic shock/resuscitation-induced liver injury through the suppression of NF- $\mathrm{kB}$ activation.

\subsubsection{Antityrosinase Effect}

Within melanosomes, tyrosinase-related protein 1 (TRP1) and tyrosinase-related protein 2 (TRP2) are two enzymes that play a major role in the production of melanins [74]. Recently, tyrosinase inhibitors have become increasingly used in pharmaceutical and medicinal agents. The study by Yoshimori et al. [75] assessed the inhibitory effect of $\alpha, \beta$, and $\gamma$ thujaplicin, isomers of hinokitiol, on human tyrosinase. The data showed that $\gamma$-thujaplicin greatly suppresses human tyrosinase with a reported $\mathrm{IC}_{50}$ of $1.15 \mu \mathrm{M}$ that could be related to interactions involving Ile368, His367, and Val377 (hot spot residues of amino acid) in human tyrosinase.

Another study by Tsao et al. [76] found that hinokitiol could play a key role in inhibiting melanogenesis, including pigmentation disorders and melanoma. The results of this study revealed that increased hinokitiol supplementation was responsible for inhibiting melanogenesis following inhibition of tyrosinase activity in B16F10 cells. Downregulation of the expression levels of the phospho-protein kinase B (P-AKT) and phospho-mammalian targets of the rapamycin (p-mTOR) signaling pathway is among the known mechanisms implicated in the tyrosinase inhibition. Therefore, hinokitiol acts as an antimelanogenic that leads to mitigate hyperpigmentation.

On the other hand, in order to establish algorithms to identify tyrosinase inhibitors from the inactive molecules using molecular descriptors to find statistical models of linear discriminant analysis (LDA), a database with 246 compounds having antityrosinase activity, including hinokitiol, was selected according to the literature data. The results obtained showed that a positive correlation was revealed between experimental results and theoretical prediction on the mushroom tyrosinase enzyme, and among the models developed, new clusters could be used as novel tyrosinase inhibitors such as ES2 with an $\mathrm{IC}_{50}=1.53 \mu \mathrm{M}$. In addition, hinokitiol showed antityrosinase activity with values below $10 \mu \mathrm{M}$ [77]. Furthermore, the objective of Sakuma et al. [78] was to verify the correlation between antityrosinase property and the redox effect of four different modes, including mode 1: catechol, hydroquinone, or phenol; mode 2: arbutin, kojic acid, resorcinol, methyl p-hydroxybenzoate, and L-tyrosine; mode 3: L-ascorbic acid and mode 4: hinokitiol. They also assessed the antityrosinase properties of these compounds. The findings indicate that hinokitiol showed a very powerful inhibitory activity $\left(\mathrm{IC}_{50}=8.22 \times 10^{-6} \mathrm{M}\right.$, $\left.\mathrm{Ki}=3.56 \times 10^{-7} \mathrm{M}\right)$ followed by hydroquinone $\left(\mathrm{IC}_{50}=5.15 \times 10^{-5} \mathrm{M}, \mathrm{Ki}=4.72 \times 10^{-6} \mathrm{M}\right)$. Additionally, based on the results of voltammetry, due to the different affinity in the associ- 
ation of phenolic components and tyrosinase, no association has been established between redox potentials and tyrosinase inhibitory activity.

\subsection{Anticancer Effects and Mechanisms}

\subsubsection{Effects on Breast Cancer}

Breast cancer (BC) remains one of the leading causes of cancer mortality in women and has attracted huge attention from investigators to find effective therapeutic strategies in order to act in the face of the emergence of this type of cancer. Monoterpenoid compounds, including hinokitiol, have shown promising preventive and therapeutic potential against $\mathrm{BC}$ development.

The study by Wang et al. [79] showed that hinokitiol was able to inhibit tumor growth in murine BC (4T1) through autophagy signaling pathways. It significantly decreased the expression levels of phosphorylated protein kinase B (AKT), mammalian target of rapamycin (mTOR), and p70 ribosomal s6 kinase (p70S6K) compared to control cells. Hinokitiol also increased the expression levels of the beclin 1 protein known for its remarkable antitumor activity, including autophagy [79]. Moreover, hinokitiol has been reported to exhibit important antitumor properties against human breast cancer AS-B244 $\left(\mathrm{IC}_{50}=33.6 \pm 8.8 \mu \mathrm{M}\right)$ and MDA-MB-231 cells $\left(\mathrm{IC}_{50}=46.6 \pm 7.5 \mu \mathrm{M}\right)$ [80]. The underlying mechanism of action revealed that hinokitiol may cause proteasomal degradation of the epidermal growth factor receptor (EGFR), and thereby inhibits the vasculogenic mimicry activity of BC cells [80]. Recently, Wu et al. [18] showed that hinokitiol inhibits cell growth, migration, and metastasis in breast (4T1) cancer cells by inhibiting heparanase expression. These effects were attributed to the downregulation of the extracellular signal-regulated kinase (ERK) and protein kinase B (Akt) pathway (Figure 2). The in vivo experiments using mice models confirmed that hinokitiol has a promising ability to impede cancer migration and metastasis by targeting the above-mentioned mechanisms [18].

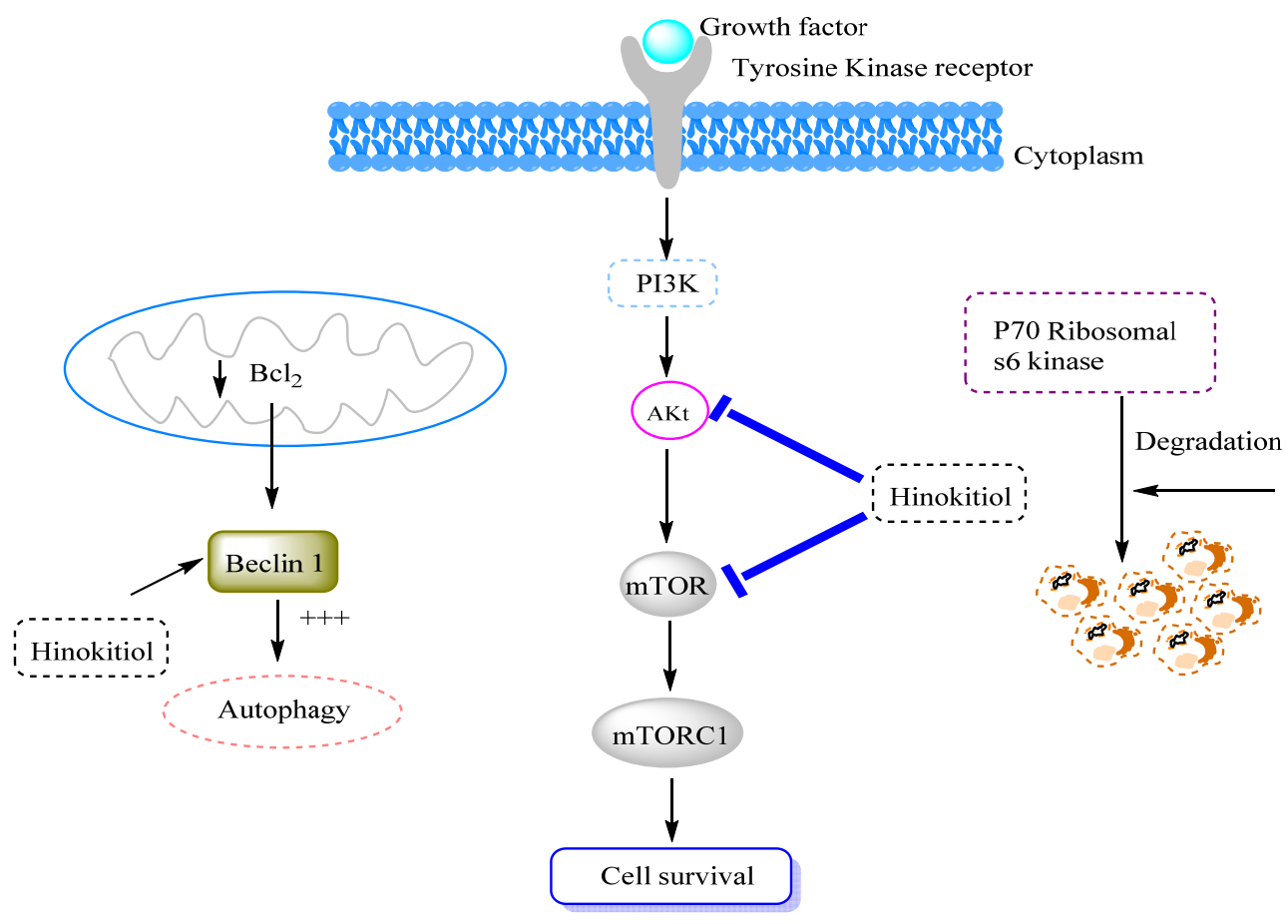

Figure 2. Antibreast cancer mechanisms of Hinokitiol. Hinokitiol exhibits its antiproliferative actions on breast cancer cell lines via three mechanisms. It induces autophagy by decreasing Bcl2 and activating Beclin 1. It can also block cell survival by inhibiting AKT and mTOR pathways. Abbreviations: mTOR: Mammalian Target of Rapamycin; Bcl2: B-cell lymphoma 2; AKT: Protein Kinase B. 
On the other hand, Chen et al. [17] demonstrated that hinokitiol activated miR-494-3p in BC stem/progenitor cells, which in turn reduced BMI-1 protein expression levels known as an oncogene by modulating the cell cycle inhibitor genes $\mathrm{p} 16$ and $\mathrm{p} 19$. The downregulation of BMI-1 expression induces the suppression of self-renewal of BC cells [17].

\subsubsection{Effects on Lung Cancer}

Lung cancer is considered to be one of the most severe types of fatal cancers in the world. Hinokitiol has been reported to be a potential phytochemical, leading to the discovery of new drugs against lung cancer, especially lung adenocarcinoma.

The study by Jayakumar and colleagues [1] showed that hinokitiol suppresses cell migration in the A549 human lung adenocarcinoma cell line at a concentration of $5 \mu \mathrm{M}$. This effect was attributed to the ability of hinokitiol to promote cell apoptosis through downregulation of p53 expression followed by attenuation of proapoptotic protein Bax, as well as the upregulation of antioxidant enzymes activity, such as catalase (CAT) and superoxide dismutase (SOD) [1]. Moreover, hinokitiol induced apoptosis via activating cytochrome c expression, mediated by caspase- $9 /-3$ activation. The authors also demonstrated that hinokitiol significantly inhibits matrix metalloproteinases MMP-2 and MMP-9 expression [1]. These findings indicated that hinokitiol suppressed the migration of A549 lung cancer cells by targeting diverse molecules and mechanisms, especially those involved in apoptotic pathways (Figure 3). In the same context, another study reported that hinokitiol induced cell apoptosis in A549 cells by generating reactive oxygen species (ROS) and upregulation of caspases 9 and 3 [81].

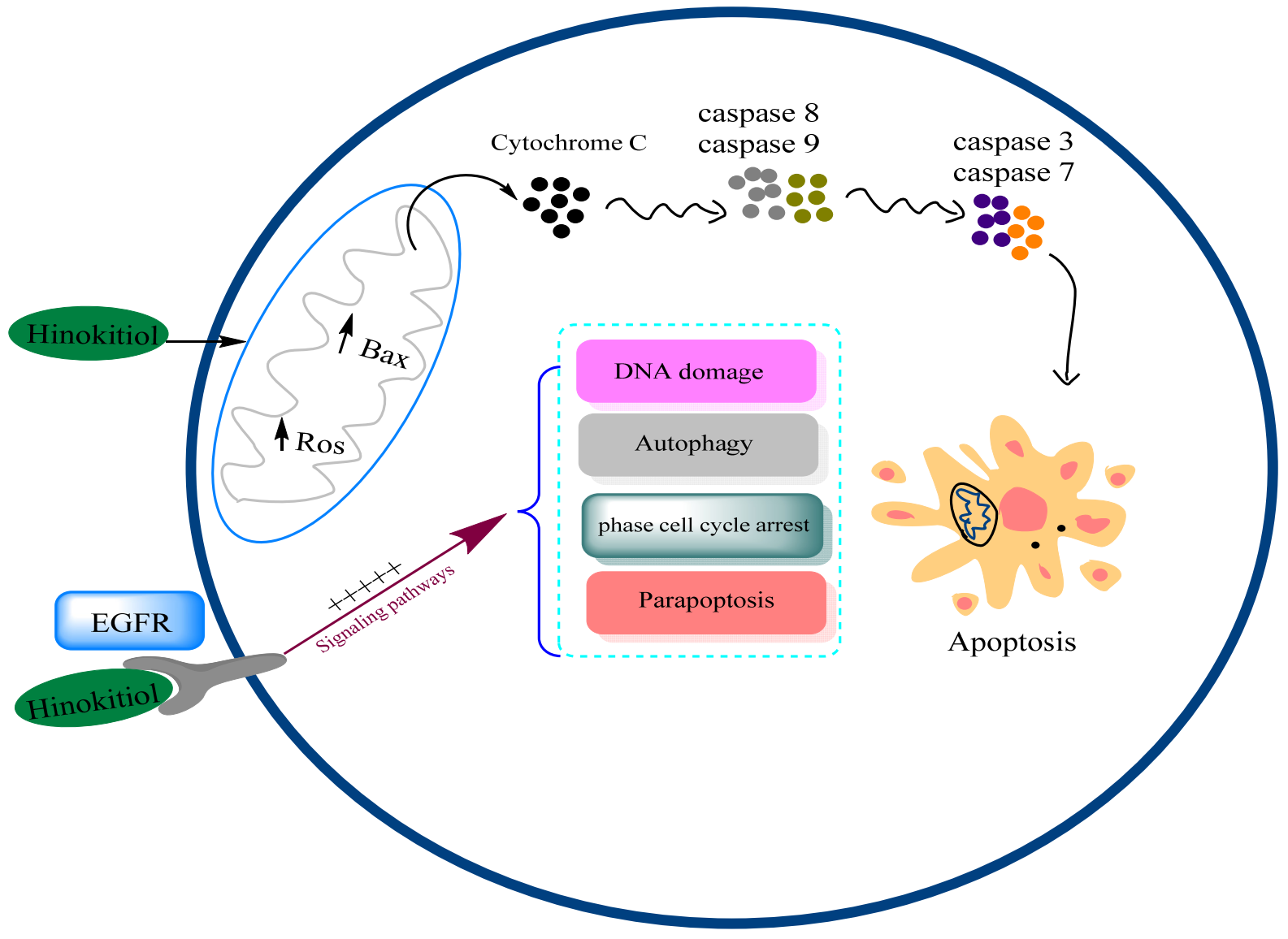

Figure 3. Anticancer mechanisms of hinokitiol on lung cancer. Hinokitiol blocks signaling pathways generated by EGFR, such as DNA damage, autophagy, phase cell cycle arrest, paraptosis. It also induces intrinsic apoptosis via the increase in ROS production and protein Bax expression. Abbreviations: EGFR: Epithelial Growth Factor Receptor ROS; Bax: Bcl-2-associated $X$ protein. 
Hinokitiol has also shown effective anticancer effects against EGFR-TKI resistance, in vitro, in H1975 and PC9-IR lung cancer cells, and in vivo by inducing DNA damage, autophagy, S-phase cell cycle arrest, and senescence [82].

On the other hand, Chen et al. [83] assessed the anticancer potential of hinokitiol copper complex (HK-Cu) on A549 and K562 lung cancer cell lines. The results showed that HK-Cu attenuates the 195 proteasomal deubiquitinases (DUBs) by inducing paraptosis-like cell death. This effect was caspase-independent and was unrelated to ROS generation but apparently depends on transcription factor 4 (ATF4) and endoplasmic reticulum (ER) stress [83]. These data demonstrated that hinokitiol could inhibit cell growth in lung cancer not only through apoptosis pathways but also by triggering other types of programmed cell death, such as paraptosis. It is a programmed caspase-independent cell death characterized by multiple cytoplasmic vacuolations derived from the swelling of the endoplasmic reticulum (ER) and mitochondria [84]. Although the precise mechanisms of action of paraptosis are not yet well investigated, it could become an effective strategy in cancer therapy.

\subsubsection{Effects on Melanoma Cancer}

Melanoma is a life-threatening skin cancer, deriving from the pigmented cells named melanocytes that are found in the basal layer of the epidermis $[85,86]$. It presents an increasing challenge in cancer therapies, especially its metastatic form, as systemic treatment continues to be ineffective. Accordingly, the development of novel drugs and strategies is strongly required. Phytochemicals, such as hinokitiol, may be a promising candidate for the treatment of metastatic melanoma (Figure 4).

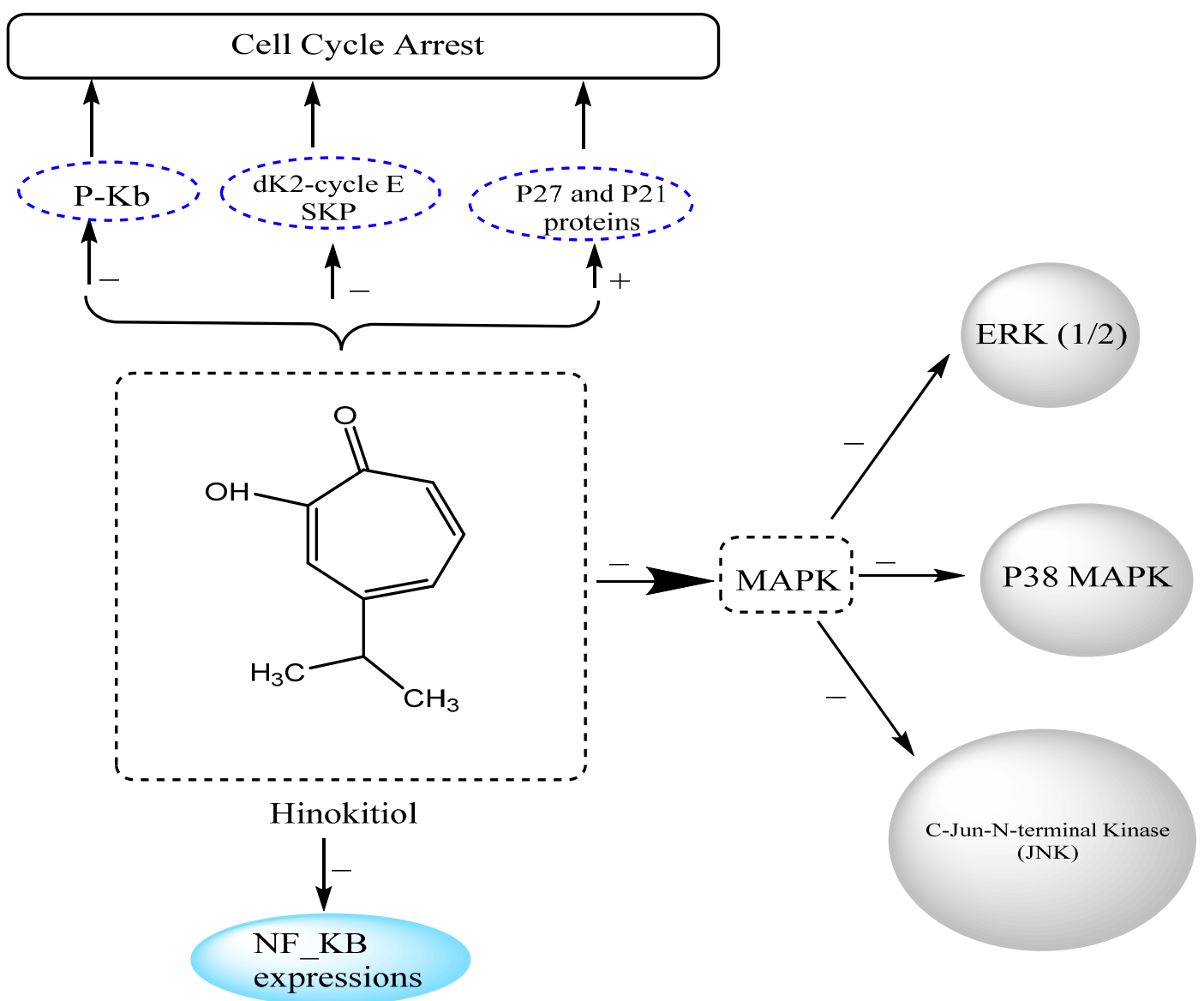

Figure 4. Anticancer mechanisms of hinokitiol against melanoma cancer. Hinokitiol exhibits its anticancer effects on melanoma cancer cell lines via the arrest of the cell cycle, the inhibition of NF- $\mathrm{B}$ expression, and the decrease in MAPK pathways. Abbreviations: NF-кB: Nuclear Factor Kappa; MAPK: Mitogen-Activated Protein Kinase; ERK: Extracellular Signal-Regulated Kinases. 
Matrix metalloproteinases (MMPs) represent one of the main targets of antimetastatic therapy due to their pivotal role in cancer migration, invasion, and metastasis. The suppression of MMPs expression and activities is defined as effective targets for primary prevention of cancer metastasis. Therefore, many current anticancer drug formulations are primarily aimed at inhibiting the expression and activities of MMPs. Indeed, hinokitiol has been shown to reduce MMP-2 and -9 expression and activity in the B16-F10 melanoma cell line. This event was associated with the upregulation of antioxidant enzymes catalase (CAT) and superoxide dismutase (SOD) [3]. Moreover, the same authors demonstrated that treatment of B16-F10 melanoma cells with hinokitiol significantly inhibits cell migration and metastasis by attenuating MMP-1 expression and suppressing MAPK signaling cascades, including extracellular signal-regulated kinase (ERK) 1/2, p38 MAPK, and c-Jun N-terminal kinases (JNK) [3]. Furthermore, hinokitiol treatment prevents the activation of nuclear factor kappa B (NF-kB) and c-Jun [87]. On the other hand, an in vivo investigation revealed that hinokitiol suppresses the formation of metastatic lung nodules and enhances histological parameters in C57BL/ 6 mice bearing B16/F10 melanoma [87].

Recently, the study by Wu and colleagues [18] identified heparanase as a major potential target of hinokitiol. This endoglycosidase participates in the degradation of the extracellular matrix by cleaving heparan sulfate, which leads to cell migration and invasion [88]. Indeed, hinokitiol has been shown to downregulate the expression levels of heparanase in B16-F10 mouse melanoma cells by targeting the ERK and Akt signaling pathways [18]. Another study by Liu and Yamauchi [86] reported that hinokitiol significantly attenuates tumor growth and DNA synthesis in FEM human melanoma cells by inducing cell cycle arrest at G1 phase. This effect was mediated by the upregulation of p27 and p21 protein levels and by the decrease in the expression of Cdk2, cyclin E, Skp2 ubiquitin ligase, and phosphorylated $\mathrm{Rb}$ [86]. Moreover, hinokitiol has also been shown to induce apoptosis in the B16-F10 melanoma cell line by decreasing survivin protein expression and activating the ERK, MKP-3, and proteosome pathways [2].

\subsubsection{Other Types of Cancer}

Hinokitiol has also been shown to have several anticancer effects against various types of cancer (Table 1), including colon, liver, oral, prostate, colorectal, stomach, and cervical cancers [79,89-92].

The study by Yang et al. [12] showed that hinokitiol exhibits effective antiproliferative effects on vascular smooth muscle cells through suppressing platelet-derived growth factor (PDGF-BB), JNK1/2 phosphorylation, and phospholipase C (PLC)- $\gamma 1$, as well as modulating the levels of proliferating cell nuclear antigen (PCNA), which consequently promotes cell cycle arrest in the G0/G1 phase [12]. Moreover, hinokitiol has been shown to inhibit cell cycle arrest at the G1/S phase and induce cell apoptosis in oral squamous carcinoma cells [93]. On the other hand, it has been reported that hinokitiol could induce cellular autophagy in colorectal cancer cells via downregulating the phosphoprotein kinase $\mathrm{B}$ (PAKT) and p-mTOR signaling pathway [79].

A recent study by Wang and colleagues [8] reported that hinokitiol induced cell growth inhibition in HeLa cervical carcinoma cells by cell cycle arrest in G1 phase, upregulation of p21 and p53 proteins, as well as downregulation of the expression of cell cycle regulatory factors, such as cyclin D and cyclin E. These events were mediated by upregulating the expression levels of autophagy proteins regulators, including beclin 1 and microtubuleassociated protein 1 light chain 3 (LC3-II) [8]. 
Table 1. Anticancer effects of hinokitiol.

\begin{tabular}{|c|c|c|c|}
\hline Cancer Type & Cell Lines & Key Results & References \\
\hline Breast cancer & $\begin{array}{l}\text { Breast and colorectal cancer } \\
\text { cells }\end{array}$ & $\begin{array}{l}\text { Induced autophagy in cancer cell lines by downregulating } \\
\text { phosphoprotein kinase B (PAKT)/p-mTOR signaling pathway }\end{array}$ & [94] \\
\hline Breast cancer & $\begin{array}{l}\text { MDA-MB-231 human breast } \\
\text { cancer cells }\end{array}$ & $\mathrm{IC}_{50}=46.6 \pm 7.5 \mu \mathrm{M}$ & [80] \\
\hline Breast cancer & $\begin{array}{l}\text { AS-B244 human breast cancer } \\
\text { cells }\end{array}$ & $\mathrm{IC}_{50}=33.6 \pm 8.8 \mu \mathrm{M}$ & [80] \\
\hline Breast cancer & Breast (4T1) cancer cells & $\begin{array}{l}\text { Inhibited cell growth, migration, and metastasis through } \\
\text { inhibiting heparanase expression }\end{array}$ & [18] \\
\hline Breast cancer & $\begin{array}{l}\text { Breast cancer stem/progenitor } \\
\text { cells (BCSCs) }\end{array}$ & $\begin{array}{l}\text { Activated miR-494-3p, which decreased BMI1 expression and } \\
\text { suppressed self-renewal of BCSCs }\end{array}$ & [17] \\
\hline Glioma cancer & U87MG glioma cells & $\mathrm{IC}_{50}=316.5 \pm 35.5 \mu \mathrm{M}$ & [95] \\
\hline Glioma cancer & T98G glioma cells & $\mathrm{IC}_{50}=152.5 \pm 25.3 \mu \mathrm{M}$ & [95] \\
\hline Teratoma cancer & Teratocarcinoma F9 cells & Triggered cell apoptosis by activating caspase- 3 & [96] \\
\hline Oral cancer & $\begin{array}{l}\text { HSC3, SAS, and SCC4 oral } \\
\text { squamous carcinoma cell lines }\end{array}$ & Resulted in a growth rate of between $15 \%$ and $45 \%$ & [6] \\
\hline Oral cancer & $\begin{array}{l}\text { Vascular smooth muscle cell } \\
\qquad \text { (VSMC) }\end{array}$ & $\begin{array}{l}\text { Inhibited }(1-10 \mu \mathrm{M}) \text { DNA synthesis and proliferation of } \\
\text { VSMC via platelet-derived growth factor-BB } \\
\text { (PDGF-BB)-induced phosphorylation of ERK1/2, Akt, PI3K or } \\
\text { JAK2 and upregulating of p21 and p53 proteins }\end{array}$ & [97] \\
\hline Oral cancer & $\begin{array}{l}\text { Oral squamous carcinoma } \\
\text { cells }\end{array}$ & $\begin{array}{l}\text { Promoted cell cycle arrest in G1 or G1/S phase and caused } \\
\text { cell apoptosis } \\
\text { Significantly inhibited pan-histone mRNA expression (at } \\
6.25-12.5 \mu \mathrm{M})\end{array}$ & [93] \\
\hline Lung cancer & $\begin{array}{l}\text { HCC827 non-small cell lung } \\
\text { cancer cell lines }\end{array}$ & $\mathrm{IC}_{50}=75.0 \pm 4.2 \mu \mathrm{M}$ & [98] \\
\hline Lung cancer & $\begin{array}{l}\text { HCC827-GRKU non-small cell } \\
\text { lung cancer cell lines }\end{array}$ & $\mathrm{IC}_{50}=74.0 \pm 2.1 \mu \mathrm{M}$ & [98] \\
\hline Lung cancer & $\begin{array}{l}\text { HCC } 827 \text { non-small cell lung } \\
\text { cancer (NSCLC) cells }\end{array}$ & $\begin{array}{l}\mathrm{IC}_{50}=37.63 \pm 5.41 \mu \mathrm{M} \\
\text { Induced apoptosis and autophagy in NCLSC }\end{array}$ & [92] \\
\hline Lung cancer & $\begin{array}{l}\text { Human A549 } \\
\text { and K562 cell lines }\end{array}$ & $\begin{array}{l}\text { Attenuated the } 19 S \text { proteasomal DUBs, triggering } \\
\text { paraptosis-like cell death }\end{array}$ & [83] \\
\hline Lung cancer & $\begin{array}{l}\text { H1975 lung adenocarcinoma } \\
\text { cells }\end{array}$ & $\mathrm{IC}_{50}=1.57 \mathrm{mM}$ & [82] \\
\hline Lung cancer & $\begin{array}{l}\text { PC9-IR lung adenocarcinoma } \\
\text { cells }\end{array}$ & $\mathrm{IC}_{50}=1.87 \mathrm{mM}$ & [82] \\
\hline Lung cancer & $\begin{array}{l}\text { A549 human lung } \\
\text { adenocarcinoma cells }\end{array}$ & $\begin{array}{l}\text { Markedly inhibited cell migration } 1-5 \mu \mathrm{M} \\
\text { Induced a significant change in the expression of p53 and Bax } \\
\text { proteins, accompanied by downregulation of caspase- } 9 \text { and }-3 \\
\text { and metalloproteinases (MMPs) }-2 /-9\end{array}$ & [1] \\
\hline Lung cancer & $\begin{array}{l}\text { A549 lung adenocarcinoma } \\
\text { Cells }\end{array}$ & $\begin{array}{l}\text { Induced apoptosis by enhancing the production of ROS and } \\
\text { the expression levels of proteins caspase- } 3 /-9\end{array}$ & [81] \\
\hline Melanoma cancer & FEM human melanoma cells & $\begin{array}{l}\text { Inhibited cell growth and DNA synthesis by blocking } \\
\text { G1-S-phase transition accompanied by increased levels of p27 } \\
\text { and p21 protein and decreased expression of Cdk2, cyclin E, } \\
\text { and phosphorylated Rb }\end{array}$ & [86] \\
\hline Melanoma cancer & B16-F10 melanoma cells & $\begin{array}{l}\text { Downregulated the expression levels and activity of MMPs-2 } \\
\text { and -9 in B16-F10 melanoma cell lines and inhibited ROS } \\
\text { generation by increasing the activity antioxidant enzymes } \\
\text { CAT and SOD }\end{array}$ & [87] \\
\hline
\end{tabular}


Table 1. Cont.

\begin{tabular}{|c|c|c|c|}
\hline Cancer Type & Cell Lines & Key Results & References \\
\hline Melanoma cancer & B16-F10 melanoma cells & $\begin{array}{l}\text { Significantly suppressed colony formation and tumor } \\
\text { viability in a time and concentration-dependent manner } \\
\text { Reduced survivin protein expressions and increased survivin } \\
\text { ubiquitination } \\
\text { Caused ERK phosphorylation accompanied by an increase in } \\
\text { the expression levels of tumor suppressor MKP-3 }\end{array}$ & [2] \\
\hline Melanoma cancer & B16-F10 melanoma cells & $\begin{array}{l}\text { Autophagy regulation of melanoma cell hyperpigmentation } \\
\text { by inhibition of microphthalmia-associated transcription } \\
\text { factor (MITF) and tyrosinase }\end{array}$ & {$[76]$} \\
\hline Melanoma cancer & B16-F10 mouse melanoma & $\begin{array}{l}\text { Antimetastatic effects and inhibition of cell viability on cancer } \\
\text { cells } \\
\text { Downregulated heparanase expression by targeting } \\
\text { extracellular signal-regulated kinase (ERK) and protein kinase } \\
\text { B (AKT) signaling pathways }\end{array}$ & {$[18]$} \\
\hline Melanoma cancer & B16-F10 melanoma cells & $\begin{array}{l}\text { Suppressed cell migration and metastasis through } \\
\text { downregulation of matrix metalloproteinase-1 (MMP-1) } \\
\text { expression and inhibition of the phosphorylation of } \\
\text { mitogen-activated protein kinase (MAPK) signaling factors } \\
\text { (ERK } 1 / 2 \text {, p38 MAPK, and c-Jun N-terminal kinases (JNK)) }\end{array}$ & {$[3]$} \\
\hline $\begin{array}{l}\text { Vascular smooth } \\
\text { muscle tumors }\end{array}$ & $\begin{array}{l}\text { Vascular smooth muscle } \\
\qquad \text { (VSM) cells }\end{array}$ & $\begin{array}{l}\text { Inhibited platelet-derived growth factor PDGF-BB- stimulated } \\
\text { proliferation of VSM cells, attenuating JNK1/2 } \\
\text { phosphorylation and phospholipase C (PLC)- } \gamma 1 \\
\text { Modulated the levels of proliferating cell nuclear antigen } \\
\text { (PCNA), promoting thus, cell cycle arrest in the G0/G1 phase }\end{array}$ & {$[12]$} \\
\hline Cervical cancer & HeLa cells & $\mathrm{IC}_{50}=38.58 \pm 6.72 \mu \mathrm{M}$ & {$[92]$} \\
\hline Cervical cancer & HeLa cervical carcinoma cells & $\begin{array}{l}\text { Inhibited the growth of tumor } \\
\text { Induced cell cycle arrest in the G1 phase } \\
\text { Upregulated levels of p53 and p21, with a concomitant } \\
\text { reduction in expression of cell cycle regulatory proteins } \\
\text { (cyclin D and cyclin E) } \\
\text { Significantly increased the expression levels of autophagy } \\
\text { regulators, including beclin } 1 \text { and microtubule-associated } \\
\text { protein } 1 \text { light chain } 3 \text { (LC3-II), in a dose-dependent manner }\end{array}$ & {$[8]$} \\
\hline Gastric cancer & $\begin{array}{l}\text { KATO-III human stomach } \\
\text { cancer }\end{array}$ & Inhibited tumor growth (54\%) at $0.32 \mathrm{mg} / \mathrm{mL}$ & {$[91]$} \\
\hline $\begin{array}{l}\text { Ehrlich ascites } \\
\text { cancer }\end{array}$ & $\begin{array}{l}\text { Ehrlich-Lettre ascites } \\
\text { cacinoma }\end{array}$ & Inhibited tumor growth $(58 \%)$ at $0.32 \mathrm{mg} / \mathrm{mL}$ & {$[91]$} \\
\hline Colon cancer & HCT-116 colon cancer cells & $\begin{array}{l}\text { Caused DNA demethylation by suppressing DNMT1 and } \\
\text { UHRF1 expression in colon cancer cell lines }\end{array}$ & {$[90]$} \\
\hline Prostate cancer & Prostate carcinoma cells & $\begin{array}{l}\text { Inhibited the cell growth } \\
\text { Induced the disruption of androgen receptor (AR) signaling } \\
\text { in prostate carcinoma cells }\end{array}$ & {$[89]$} \\
\hline Liver cancer & $\begin{array}{l}\text { Human } \\
\text { hepatocellularcarcinoma }\end{array}$ & $\begin{array}{l}\text { Triggered cell autophagy mediated by ROS- induced } \\
\text { downregulation of Akt-mTOR } \\
\text { Induced cell apoptosis by targeting mitochondrial-dependent } \\
\text { pathway }\end{array}$ & {$[11]$} \\
\hline
\end{tabular}

\section{Conclusions}

Here, the sources and main pharmacological properties of hinokitiol were reported and highlighted. The analysis of different published works showed that this natural compound exhibits remarkable biological effects in particularly against cancer cell lines. Indeed, cellular and molecular studies demonstrated that hinokitiol blocks and inhibits the 
main check points of breast, lung, and melanoma cancer with different mechanisms. This suggests that it can be a promising candidate as an anticancer drug. Moreover, the antiinflammatory, antioxidant, and antimicrobial properties of this molecule can consider it as an important bioactive substance in cancer prevention. However, more understanding of its pharmacodynamics and pharmacokinetics is required for its incorporation as a drug in chemotherapy. Moreover, the validation of its safety is also needed, via further toxicological investigation.

Author Contributions: Conceptualization, N.E.H.; F.L.; A.K.; S.B.; methodology, N.E.O.; A.B. (Abdelhakim Bouyahya); M.A.S.; G.Z.; software, N.E.H.; K.F.-B.; validation, M.A.S., A.B. (Abdelaali Balahbib); formal analysis, A.B. (Abdelhakim Bouyahya); investigation, N.E.H.; A.B. (Abdelaali Balahbib); resources, A.B. (Abdelhakim Bouyahya); data curation, N.E.O.; writingoriginal draft preparation, N.E.H., N.E.O., A.B. (Abdelhakim Bouyahya); writing-review and editing, G.Z., C.F., L.M., G.O.; visualization, G.Z.; supervision, A.B. (Abdelhakim Bouyahya); project administration, A.B. (Abdelhakim Bouyahya); funding acquisition, C.F., L.M. All authors have read and agreed to the published version of the manuscript.

Funding: This research received no external funding.

Institutional Review Board Statement: Not applicable.

Informed Consent Statement: Not applicable.

Data Availability Statement: Not applicable.

Acknowledgments: The present article is part of the third mission activities of the Botanic Garden "Giardino dei Semplici" planned for the 20th anniversary of the establishment.

Conflicts of Interest: The authors declare no conflict of interest.

\section{References}

1. Jayakumar, T.; Liu, C.-H.; Wu, G.-Y.; Lee, T.-Y.; Manubolu, M.; Hsieh, C.-Y.; Yang, C.-H.; Sheu, J.-R. Hinokitiol Inhibits Migration of A549 Lung Cancer Cells via Suppression of MMPs and Induction of Antioxidant Enzymes and Apoptosis. Int. J. Mol. Sci. 2018, 19, 939. [CrossRef] [PubMed]

2. Wei, K.-C.; Chen, R.-F.; Chen, Y.-F.; Lin, C.-H. Hinokitiol Suppresses Growth of B16 Melanoma by Activating ERK/MKP3/ Proteosome Pathway to Downregulate Survivin Expression. Toxicol. Appl. Pharmacol. 2019, 366, 35-45. [CrossRef] [PubMed]

3. Huang, C.-H.; Lu, S.-H.; Chang, C.-C.; Thomas, P.A.; Jayakumar, T.; Sheu, J.-R. Hinokitiol, a Tropolone Derivative, Inhibits Mouse Melanoma (B16-F10) Cell Migration and in Vivo Tumor Formation. Eur. J. Pharmacol. 2015, 746, 148-157. [CrossRef]

4. Nagao, Y.; Sata, M. Effect of Oral Care Gel on the Quality of Life for Oral Lichen Planus in Patients with Chronic HCV Infection. Virol. J. 2011, 8, 1-5. [CrossRef] [PubMed]

5. Gilbard, J.P.; Douyon, Y.; Huson, R.B. Time-Kill Assay Results for a Linalool-Hinokitiol-Based Eyelid Cleanser for Lid Hygiene. Cornea 2010, 29, 559-563. [CrossRef] [PubMed]

6. Shih, Y.-H.; Chang, K.-W.; Hsia, S.-M.; Yu, C.-C.; Fuh, L.-J.; Chi, T.-Y.; Shieh, T.-M. In Vitro Antimicrobial and Anticancer Potential of Hinokitiol against Oral Pathogens and Oral Cancer Cell Lines. Microbiol. Res. 2013, 168, 254-262. [CrossRef]

7. Domon, H.; Hiyoshi, T.; Maekawa, T.; Yonezawa, D.; Tamura, H.; Kawabata, S.; Yanagihara, K.; Kimura, O.; Kunitomo, E.; Terao, Y. Antibacterial Activity of Hinokitiol against Both Antibiotic-Resistant and-Susceptible Pathogenic Bacteria That Predominate in the Oral Cavity and Upper Airways. Microbiol. Immunol. 2019, 63, 213-222. [CrossRef]

8. Wang, Y.; Liu, X.; Chen, T.; Xu, Y.; Tian, S. Antifungal Effects of Hinokitiol on Development of Botrytis Cinerea in Vitro and in Vivo. Postharvest Biol. Technol. 2020, 159, 111038. [CrossRef]

9. Lee, J.-H.; Moon, J.-H.; Lee, Y.-J.; Park, S.-Y. SIRT1, a Class III Histone Deacetylase, Regulates LPS-Induced Inflammation in Human Keratinocytes and Mediates the Anti-Inflammatory Effects of Hinokitiol. J. Investig. Dermatol. 2017, 137, 1257-1266. [CrossRef]

10. Ye, J.; Xu, Y.F.; Lou, L.X.; Jin, K.; Miao, Q.; Ye, X.; Xi, Y. Anti-Inflammatory Effects of Hinokitiol on Human Corneal Epithelial Cells: An in Vitro Study. Eye 2015, 29, 964-971. [CrossRef] [PubMed]

11. Zhang, G.; He, J.; Ye, X.; Zhu, J.; Hu, X.; Shen, M.; Ma, Y.; Mao, Z.; Song, H.; Chen, F. $\beta$-Thujaplicin Induces Autophagic Cell Death, Apoptosis, and Cell Cycle Arrest through ROS-Mediated Akt and P38/ERK MAPK Signaling in Human Hepatocellular Carcinoma. Cell Death Dis. 2019, 10, 1-14. [CrossRef] [PubMed]

12. Yang, P.-S.; Wang, M.-J.; Jayakumar, T.; Chou, D.-S.; Ko, C.-Y.; Hsu, M.-J.; Hsieh, C.-Y. Antiproliferative Activity of Hinokitiol, a Tropolone Derivative, Is Mediated via the Inductions of p-JNK and p-PLC $\gamma 1$ Signaling in PDGF-BB-Stimulated Vascular Smooth Muscle Cells. Molecules 2015, 20, 8198-8212. [CrossRef] 
13. Koufaki, M.; Theodorou, E.; Alexi, X.; Nikoloudaki, F.; Alexis, M.N. Synthesis of Tropolone Derivatives and Evaluation of Their in Vitro Neuroprotective Activity. Eur. J. Med. Chem. 2010, 45, 1107-1112. [CrossRef]

14. Krenn, B.M.; Gaudernak, E.; Holzer, B.; Lanke, K.; Van Kuppeveld, F.J.M.; Seipelt, J. Antiviral Activity of the Zinc Ionophores Pyrithione and Hinokitiol against Picornavirus Infections. J. Virol. 2009, 83, 58-64. [CrossRef] [PubMed]

15. Fujisaki, R.; Kamei, K.; Yamamura, M.; Nishiya, H.; Inouye, S.; Takahashi, M.; Abe, S. In Vitro and in Vivo Anti-Plasmodial Activity of Essential Oils, Including Hinokitiol. Southeast Asian J. Trop. Med. Public Health 2012, 43, 270-279. [PubMed]

16. Lu, W.-J.; Lin, K.-H.; Tseng, M.-F.; Yuan, K.-C.; Huang, H.-C.; Sheu, J.-R.; Chen, R.-J. New Therapeutic Strategy of Hinokitiol in Haemorrhagic Shock-Induced Liver Injury. J. Cell. Mol. Med. 2019, 23, 1723-1734. [CrossRef] [PubMed]

17. Chen, S.-M.; Wang, B.-Y.; Lee, C.-H.; Lee, H.-T.; Li, J.-J.; Hong, G.-C.; Hung, Y.-C.; Chien, P.-J.; Chang, C.-Y.; Hsu, L.-S. Hinokitiol Up-Regulates MiR-494-3p to Suppress BMI1 Expression and Inhibits Self-Renewal of Breast Cancer Stem/Progenitor Cells. Oncotarget 2017, 8, 76057. [CrossRef]

18. Wu, Y.-J.; Hsu, W.-J.; Wu, L.-H.; Liou, H.-P.; Pangilinan, C.R.; Tyan, Y.-C.; Lee, C.-H. Hinokitiol Reduces Tumor Metastasis by Inhibiting Heparanase via Extracellular Signal-Regulated Kinase and Protein Kinase B Pathway. Int. J. Med. Sci. 2020, 17, 403. [CrossRef]

19. Hiyoshi, T.; Domon, H.; Maekawa, T.; Yonezawa, D.; Kunitomo, E.; Tabeta, K.; Terao, Y. Protective Effect of Hinokitiol against Periodontal Bone Loss in Ligature-Induced Experimental Periodontitis in Mice. Arch. Oral Biol. 2020, 112, 104679. [CrossRef]

20. Lin, K.H.; Kuo, J.R.; Lu, W.J.; Chung, C.L.; Chou, D.S.; Huang, S.Y.; Lee, H.C.; Sheu, J.R. Hinokitiol Inhibits Platelet Activation Ex Vivo and Thrombus Formation in Vivo. Biochem. Pharmacol. 2013, 85, 1478-1485. [CrossRef]

21. Shih, M.F.; Chen, L.Y.; Tsai, P.J.; Cherng, J.Y. In Vitro and in Vivo Therapeutics of $\beta$-Thujaplicin on LPS-Induced Inflammation in Macrophages and Septic Shock in Mice. Int. J. Immunopathol. Pharmacol. 2012, 25, 39-48. [CrossRef] [PubMed]

22. Nozoe, T. Über die farbstoffe im holzteile des "hinokl"-baumes. i. hinokitin und hinokitiol (Vorläufige Mitteilung). Bull. Chem. Soc. Jpn. 1936, 11, 295-298. [CrossRef]

23. Morita, Y.; Matsumura, E.; Okabe, T.; Fukui, T.; Ohe, T.; Ishida, N.; Inamori, Y. Biological Activity of $\beta$-Dolabrin, $\gamma$-Thujaplicin, and 4-Acetyltropolone, Hinokitiol-Related Compounds. Biol. Pharm. Bull. 2004, 27, 1666-1669. [CrossRef] [PubMed]

24. Suzuki, H.; Ueda, T.; Juránek, I.; Yamamoto, S.; Katoh, T.; Node, M.; Suzuki, T. Hinokitiol, a Selective Inhibitor of the Platelet-Type Isozyme of Arachidonate 12-Lipoxygenase. Biochem. Biophys. Res. Commun. 2000, 275, 885-889. [CrossRef] [PubMed]

25. Nozoe, T.; Takase, K.; Ogata, M. $\beta$-Dolabrin: A New Natural Tropolone. Chem. Ind. 1957, 1070.

26. Nozoe, T.; Seto, S.; Kikuchi, K.; Takeda, H. On the Synthesis of $\gamma$-Thujaplicin p-Isopropyltropolone. Proc. Jpn. Acad. 1951, 27, 146-148. [CrossRef]

27. Suzuki, R.; Inoue, Y.; Murata, I.; Nomura, H.; Isshiki, Y.; Hashimoto, M.; Kudo, Y.; Kitagishi, H.; Kondo, S.; Kanamoto, I. Preparation, Characterization, and Study of the Antimicrobial Activity of a Hinokitiol-Copper (II) $/ \gamma$-Cyclodextrin Ternary Complex. J. Mol. Struct. 2019, 1194, 19-27. [CrossRef]

28. Rebia, R.A.; Tanaka, T. Natural Antibacterial Reagents (Centella, Propolis, and Hinokitiol) Loaded into Poly [(R)-3Hydroxybutyrate-Co-(R)-3-Hydroxyhexanoate] Composite Nanofibers for Biomedical Applications. Nanomaterials 2019, 9, 1665. [CrossRef]

29. Inamori, Y.; Muro, C.; Sajima, E.; Katagiri, M.; Okamoto, Y.; Tanaka, H.; Sakagami, Y.; Tsujibo, H. Biological Activity of Purpurogallin. Biosci. Biotechnol. Biochem. 1997, 61, 890-892. [CrossRef]

30. Chang, K.-C.; Lin, D.-J.; Wu, Y.-R.; Chang, C.-W.; Chen, C.-H.; Ko, C.-L.; Chen, W.-C. Characterization of Genipin-Crosslinked Gelatin/Hyaluronic Acid-Based Hydrogel Membranes and Loaded with Hinokitiol: In Vitro Evaluation of Antibacterial Activity and Biocompatibility. Mater. Sci. Eng. C 2019, 105, 110074. [CrossRef]

31. Chang, K.-C.; Chen, W.-C.; Chen, C.-H.; Ko, C.-L.; Liu, S.-M.; Chen, J.-C. Chemical Cross-Linking on Gelatin-Hyaluronan Loaded with Hinokitiol for the Preparation of Guided Tissue Regeneration Hydrogel Membranes with Antibacterial and Biocompatible Properties. Mater. Sci. Eng. C 2021, 119, 111576. [CrossRef]

32. Huang, M.-H.; Shen, Y.-F.; Hsu, T.-T.; Huang, T.-H.; Shie, M.-Y. Physical Characteristics, Antimicrobial and Odontogenesis Potentials of Calcium Silicate Cement Containing Hinokitiol. Mater. Sci. Eng. C 2016, 65, 1-8. [CrossRef]

33. Inoue, Y.; Suzuki, R.; Murata, I.; Nomura, H.; Isshiki, Y.; Kanamoto, I. Evaluation of Antibacterial Activity Expression of the Hinokitiol/Cyclodextrin Complex against Bacteria. ACS Omega 2020, 5, 27180-27187. [CrossRef] [PubMed]

34. Ishii, J.; Omura, H.; Mitsui, T.; Eguchi, N.; Ueno, T.; Goto, H.; Ito, H. Effects of a Combination of Hinokitiol ( $\beta$-Thujaplicin) and an Organic Acid Mixture on Ruminal Fermentation in Heifers Fed a High-Grain Diet. Anim. Sci. J. 2012, 83, 36-42. [CrossRef] [PubMed]

35. Morita, Y.; Matsumura, E.; Okabe, T.; Fukui, T.; Shibata, M.; Sugiura, M.; Ohe, T.; Tsujibo, H.; Ishida, N.; Inamori, Y. Biological Activity of $\alpha$-Thujaplicin, the Isomer of Hinokitiol. Biol. Pharm. Bull. 2004, 27, 899-902. [CrossRef]

36. Zeighampour, F.; Alihosseini, F.; Morshed, M.; Rahimi, A.A. Comparison of Prolonged Antibacterial Activity and Release Profile of Propolis-Incorporated PVA Nanofibrous Mat, Microfibrous Mat, and Film. J. Appl. Polym. Sci. 2018, 135, 45794. [CrossRef]

37. Morita, Y.; Sakagami, Y.; Okabe, T.; Ohe, T.; Inamori, Y.; Ishida, N. The Mechanism of the Bactericidal Activity of Hinokitiol. Biocontrol Sci. 2007, 12, 101-110. [CrossRef]

38. Trust, T.J.; Coombs, R.W. Antibacterial Activity of $\beta$-Thujaplicin. Can. J. Microbiol. 1973, 19, 1341-1346. [CrossRef]

39. Mori, T.; Hirose, H.; Hanjavanit, C.; Hatai, K. Antifungal Activities of Plant Extracts against Some Aquatic Fungi. Biocontrol Sci. 2002, 7, 187-191. [CrossRef] 
40. Saniewska, A.; Saniewski, M. The Inhibitory Effect of Tropolone and Hinokitiol on the Mycelium Growth of Phoma Narcissi in Vitro. Acta Agrobot. 2007, 60, 107-112. [CrossRef]

41. Komaki, N.; Watanabe, T.; Ogasawara, A.; Sato, N.; Mikami, T.; Matsumoto, T. Antifungal Mechanism of Hinokitiol against Candida Albicans. Biol. Pharm. Bull. 2008, 31, 735-737. [CrossRef]

42. Saniewska, A.; Jarecka, M. The Inhibitory Effect of Tropolone and Hinokitiol on the Growth and Development of Fusarium Oxysporum f. Sp. Tulipae. Phytopathol Pol 2008, 50, 33-41.

43. Hu, J.; Shen, Y.; Pang, S.; Gao, Y.; Xiao, G.; Li, S.; Xu, Y. Application of Hinokitiol Potassium Salt for Wood Preservative. J. Environ. Sci. 2013, 25, S32-S35. [CrossRef]

44. Jin, X.; Zhang, M.; Lu, J.; Duan, X.; Chen, J.; Liu, Y.; Chang, W.; Lou, H. Hinokitiol Chelates Intracellular Iron to Retard Fungal Growth by Disturbing Mitochondrial Respiration. J. Adv. Res. 2021, in press. [CrossRef]

45. Morita, Y.; Matsumura, E.; Okabe, T.; Shibata, M.; Sugiura, M.; Ohe, T.; Tsujibo, H.; Ishida, N.; Inamori, Y. Biological Activity of Tropolone. Biol. Pharm. Bull. 2003, 26, 1487-1490. [CrossRef] [PubMed]

46. Uchide, N.; Ohyama, K.; Bessho, T.; Yuan, B.; Yamakawa, T. Effect of Antioxidants on Apoptosis Induced by Influenza Virus Infection: Inhibition of Viral Gene Replication and Transcription with Pyrrolidine Dithiocarbamate. Antiviral Res. 2002, 56, 207-217. [CrossRef]

47. Korant, B.D.; Kauer, J.C.; Butterworth, B.E. Zinc Ions Inhibit Replication of Rhinoviruses. Nature 1974, 248, 588-590. [CrossRef] [PubMed]

48. Suara, R.O.; Crowe, J.E., Jr. Effect of Zinc Salts on Respiratory Syncytial Virus Replication. Antimicrob. Agents Chemother. 2004, 48, 783-790. [CrossRef] [PubMed]

49. Beaufay, C.; Bero, J.; Quetin-Leclercq, J. Antimalarial terpenic compounds isolated from plants used in traditional medicine (2010-July 2016). In Natural Antimicrobial Agents; Springer: Berlin/Heidelberg, Germany, 2018; pp. $247-268$.

50. Barnard, J.F.; Vander Jagt, D.L.; Honek, J.F. Small Molecule Probes of Glyoxalase I and Glyoxalase II. Biochim. Biophys. Acta BBA-Protein Struct. Mol. Enzymol. 1994, 1208, 127-135. [CrossRef]

51. Ishiyama, A.; Iwatsuki, M.; Yamamoto, T.; Miura, H.; Ōmura, S.; Otoguro, K. Antimalarial Tropones and Their Plasmodium Falciparum Glyoxalase I (Pf GLOI) Inhibitory Activity. J. Antibiot. 2014, 67, 545-547. [CrossRef] [PubMed]

52. Chisty, M.M.; Nargis, M.; Inaba, T.; Ishita, K.; Osanai, A.; Kamiya, H. Transmission Electron Microscopy of Schistosoma Mansoni Cercariae Treated with Hinokitiol ( $\beta$-Thujaplicin), a Compound for Potential Skin Application against Cercarial Penetration. Tohoku J. Exp. Med. 2004, 202, 63-67. [CrossRef]

53. Rivas, F.; Medeiros, A.; Arce, E.R.; Comini, M.; Ribeiro, C.M.; Pavan, F.R.; Gambino, D. New Heterobimetallic Ferrocenyl Derivatives: Evaluation of Their Potential as Prospective Agents against Trypanosomatid Parasites and Mycobacterium Tuberculosis. J. Inorg. Biochem. 2018, 187, 73-84. [CrossRef]

54. Chen, Y.; Zeng, L.; Xiong, W.; Song, M.; Du, H.; Wang, Y.; Ming, K.; Wu, Y.; Wang, D.; Hu, Y. Anti-Duck Virus Hepatitis Mechanisms of Bush Sophora Root Polysaccharide and Its Sulfate Verified by Intervention Experiments. Virus Res. 2015, 204, 58-67. [CrossRef]

55. Chen, Y.; Yang, Y.; Wang, F.; Yang, X.; Yao, F.; Ming, K.; Yuan, W.; Zeng, L.; Liu, J. Antiviral Effect of Baicalin Phospholipid Complex against Duck Hepatitis A Virus Type 1. Poult. Sci. 2018, 97, 2722-2732. [CrossRef]

56. Okumura, S.; Hoshino, M.; Joshita, K.; Nishinomiya, T.; Murata, M. Hinokitiol Inhibits Polyphenol Oxidase and Enzymatic Browning. Food Sci. Technol. Res. 2011, 17, 251-256. [CrossRef]

57. Yamane, M.; Adachi, Y.; Yoshikawa, Y.; Sakurai, H. A New Anti-Diabetic Zn (II)-Hinokitiol ( $\beta$-Thujaplicin) Complex with Zn (O4) Coordination Mode. Chem. Lett. 2005, 34, 1694-1695. [CrossRef]

58. Naito, Y.; Yoshikawa, Y.; Yasui, H. Cellular Mechanism of Zinc-Hinokitiol Complexes in Diabetes Mellitus. Bull. Chem. Soc. Jpn. 2011, 84, 298-305. [CrossRef]

59. Byeon, S.E.; Lee, Y.G.; Kim, J.-C.; Han, J.G.; Lee, H.Y.; Cho, J.Y. Hinokitiol, a Natural Tropolone Derivative, Inhibits TNF- $\alpha$ Production in LPS-Activated Macrophages via Suppression of NF-KB. Planta Med. 2008, 74, 828-833. [CrossRef] [PubMed]

60. Li, J.; Zhou, X.; Yang, K.; Chen, W.; Jiang, L.; Bao, J.; Wu, L.; Xiong, Y. Hinokitiol Reduces Matrix Metalloproteinase Expression by Inhibiting Wnt/ $\beta$-Catenin Signaling in Vitro and in Vivo. Int. Immunopharmacol. 2014, 23, 85-91. [CrossRef] [PubMed]

61. Shih, Y.-H.; Lin, D.-J.; Chang, K.-W.; Hsia, S.-M.; Ko, S.-Y.; Lee, S.-Y.; Hsue, S.-S.; Wang, T.-H.; Chen, Y.-L.; Shieh, T.-M. Evaluation Physical Characteristics and Comparison Antimicrobial and Anti-Inflammation Potentials of Dental Root Canal Sealers Containing Hinokitiol in Vitro. PLoS ONE 2014, 9, e94941.

62. Ford, J.; Jiang, M.; Milner, J.O. Cancer-Specific Functions of SIRT1 Enable Human Epithelial Cancer Cell Growth and Survival. Cancer Res. 2005, 65, 10457-10463. [CrossRef]

63. Howitz, K.T.; Bitterman, K.J.; Cohen, H.Y.; Lamming, D.W.; Lavu, S.; Wood, J.G.; Zipkin, R.E.; Chung, P.; Kisielewski, A.; Zhang, L.-L. Small Molecule Activators of Sirtuins Extend Saccharomyces Cerevisiae Lifespan. Nature 2003, 425, 191-196. [CrossRef]

64. Jayakumar, T.; Hsu, W.-H.; Yen, T.-L.; Luo, J.-Y.; Kuo, Y.-C.; Fong, T.-H.; Sheu, J.-R. Hinokitiol, a Natural Tropolone Derivative, Offers Neuroprotection from Thromboembolic Stroke in Vivo. Evid. Based Complement. Alternat. Med. 2013, 2013. [CrossRef]

65. Varier, K.M.; Sumathi, T. Hinokitiol Offers Neuroprotection against 6-OHDA-Induced Toxicity in SH-SY5Y Neuroblastoma Cells by Downregulating MRNA Expression of MAO/ $\alpha$-Synuclein/LRRK2/PARK7/PINK1/PTEN Genes. Neurotox. Res. 2019, 35, 945-954. [CrossRef] 
66. Moon, J.-H.; Lee, J.-H.; Lee, Y.-J.; Park, S.-Y. Hinokitiol Protects Primary Neuron Cells against Prion Peptide-Induced Toxicity via Autophagy Flux Regulated by Hypoxia Inducing Factor-1. Oncotarget 2016, 7, 29944. [CrossRef] [PubMed]

67. Sajadi Hezaveh, Z.; Shidfar, F. Hydrophilic Phytochelators in Iron Overload Condition. J. Nutr. Food Secur. $2019,4,142-151$.

68. Wu, Y.-H.; Taya, Y.; Kuraji, R.; Ito, H.; Soeno, Y.; Numabe, Y. Dynamic Microstructural Changes in Alveolar Bone in LigatureInduced Experimental Periodontitis. Odontology 2019, 108, 339-349. [CrossRef]

69. Van Dyke, T.E.; Serhan, C.N. Resolution of Inflammation: A New Paradigm for the Pathogenesis of Periodontal Diseases. J. Dent. Res. 2003, 82, 82-90. [CrossRef] [PubMed]

70. Kelley, N.; Jeltema, D.; Duan, Y.; He, Y. The NLRP3 Inflammasome: An Overview of Mechanisms of Activation and Regulation. Int. J. Mol. Sci. 2019, 20, 3328. [CrossRef]

71. Liu, H.Q. Improving the hemocompatibility of stents. In Hemocompatibility of Biomaterials for Clinical Applications; Elsevier: Amsterdam, The Netherlands, 2018; pp. 379-394.

72. Kalathottukaren, M.T.; Kizhakkedathu, J.N. Mechanisms of blood coagulation in response to biomaterials: Extrinsic factors. In Hemocompatibility of Biomaterials for Clinical Applications; Elsevier: Amsterdam, The Netherlands, 2018; pp. 29-49.

73. Jayakumar, T.; Yang, C.-H.; Geraldine, P.; Yen, T.-L.; Sheu, J.-R. The Pharmacodynamics of Antiplatelet Compounds in Thrombosis Treatment. Expert Opin. Drug Metab. Toxicol. 2016, 12, 615-632. [CrossRef]

74. Ito, S.; Nakanishi, Y.; Valenzuela, R.K.; Brilliant, M.H.; Kolbe, L.; Wakamatsu, K. Usefulness of Alkaline Hydrogen Peroxide Oxidation to Analyze Eumelanin and Pheomelanin in Various Tissue Samples: Application to Chemical Analysis of Human Hair Melanins. Pigment Cell Melanoma Res. 2011, 24, 605-613. [CrossRef] [PubMed]

75. Yoshimori, A.; Oyama, T.; Takahashi, S.; Abe, H.; Kamiya, T.; Abe, T.; Tanuma, S. Structure-Activity Relationships of the Thujaplicins for Inhibition of Human Tyrosinase. Bioorg. Med. Chem. 2014, 22, 6193-6200. [CrossRef]

76. Tsao, Y.-T.; Huang, Y.-F.; Kuo, C.-Y.; Lin, Y.-C.; Chiang, W.-C.; Wang, W.-K.; Hsu, C.-W.; Lee, C.-H. Hinokitiol Inhibits Melanogenesis via AKT/MTOR Signaling in B16F10 Mouse Melanoma Cells. Int. J. Mol. Sci. 2016, 17, 248. [CrossRef] [PubMed]

77. Casañola-Martín, G.M.; Marrero-Ponce, Y.; Khan, M.T.H.; Ather, A.; Sultan, S.; Torrens, F.; Rotondo, R. TOMOCOMD-CARDD Descriptors-Based Virtual Screening of Tyrosinase Inhibitors: Evaluation of Different Classification Model Combinations Using Bond-Based Linear Indices. Bioorg. Med. Chem. 2007, 15, 1483-1503. [CrossRef]

78. Sakuma, K.; Ogawa, M.; Sugibayashi, K.; Yamada, K.; Yamamoto, K. Relationship between Tyrosinase Inhibitory Action and Oxidation-Reduction Potential of Cosmetic Whitening Ingredients and Phenol Derivatives. Arch. Pharm. Res. 1999, 22, 335-339. [CrossRef]

79. Wang, W.-K.; Lin, S.-T.; Chang, W.-W.; Liu, L.-W.; Li, T.Y.-T.; Kuo, C.-Y.; Hsieh, J.-L.; Lee, C.-H. Hinokitiol Induces Autophagy in Murine Breast and Colorectal Cancer Cells. Environ. Toxicol. 2016, 31, 77-84. [CrossRef] [PubMed]

80. Tu, D.-G.; Yu, Y.; Lee, C.-H.; Kuo, Y.-L.; Lu, Y.-C.; Tu, C.-W.; Chang, W.-W. Hinokitiol Inhibits Vasculogenic Mimicry Activity of Breast Cancer Stem/Progenitor Cells through Proteasome-Mediated Degradation of Epidermal Growth Factor Receptor. Oncol. Lett. 2016, 11, 2934-2940. [CrossRef]

81. Shen, Y.-F.; Ho, C.-C.; Shie, M.-Y.; Wang, K.; Fang, H.-Y. Hinokitiol-Loaded Mesoporous Calcium Silicate Nanoparticles Induce Apoptotic Cell Death through Regulation of the Function of MDR1 in Lung Adenocarcinoma Cells. Materials 2016, 9, 306. [CrossRef]

82. Li, L.-H.; Wu, P.; Lee, J.-Y.; Li, P.-R.; Hsieh, W.-Y.; Ho, C.-C.; Ho, C.-L.; Chen, W.-J.; Wang, C.-C.; Yen, M.-Y. Hinokitiol Induces DNA Damage and Autophagy Followed by Cell Cycle Arrest and Senescence in Gefitinib-Resistant Lung Adenocarcinoma Cells. PLOS ONE 2014, 9, e104203.

83. Chen, X.; Zhang, X.; Chen, J.; Yang, Q.; Yang, L.; Xu, D.; Zhang, P.; Wang, X.; Liu, J. Hinokitiol Copper Complex Inhibits Proteasomal Deubiquitination and Induces Paraptosis-like Cell Death in Human Cancer Cells. Eur. J. Pharmacol. 2017, 815, 147-155. [CrossRef]

84. Khalili, M.; Radosevich, J.A. Paraptosis. In Apoptosis and Beyond: Many Ways Cells Die; Wiley: Hoboken, NJ, USA, 2018; pp. 343-366.

85. Gray-Schopfer, V.C.; Karasarides, M.; Hayward, R.; Marais, R. Tumor Necrosis Factor- $\alpha$ Blocks Apoptosis in Melanoma Cells When BRAF Signaling Is Inhibited. Cancer Res. 2007, 67, 122-129. [CrossRef]

86. Liu, S.; Yamauchi, H. P27-Associated G1 Arrest Induced by Hinokitiol in Human Malignant Melanoma Cells Is Mediated via down-Regulation of PRb, Skp2 Ubiquitin Ligase, and Impairment of Cdk2 Function. Cancer Lett. 2009, 286, 240-249. [CrossRef]

87. Huang, C.-H.; Jayakumar, T.; Chang, C.-C.; Fong, T.-H.; Lu, S.-H.; Thomas, P.A.; Choy, C.-S.; Sheu, J.-R. Hinokitiol Exerts Anticancer Activity through Downregulation of MMPs 9/2 and Enhancement of Catalase and SOD Enzymes: In Vivo Augmentation of Lung Histoarchitecture. Molecules 2015, 20, 17720-17734. [CrossRef]

88. Vlodavsky, I.; Ilan, N.; Naggi, A.; Casu, B. Heparanase: Structure, Biological Functions, and Inhibition by Heparin-Derived Mimetics of Heparan Sulfate. Curr. Pharm. Des. 2007, 13, 2057-2073. [CrossRef]

89. Liu, S.; Yamauchi, H. Hinokitiol, a Metal Chelator Derived from Natural Plants, Suppresses Cell Growth and Disrupts Androgen Receptor Signaling in Prostate Carcinoma Cell Lines. Biochem. Biophys. Res. Commun. 2006, 351, 26-32. [CrossRef]

90. Seo, J.S.; Choi, Y.H.; Moon, J.W.; Kim, H.S.; Park, S.-H. Hinokitiol Induces DNA Demethylation via DNMT1 and UHRF1 Inhibition in Colon Cancer Cells. BMC Cell Biol. 2017, 18, 1-11. [CrossRef]

91. Matsumura, E.; Morita, Y.; Date, T.; Tsujibo, H.; Yasuda, M.; Okabe, T.; Ishida, N.; Inamori, Y. Cytotoxicity of the Hinokitiol-Related Compounds, $\gamma$-Thujaplicin and $\beta$-Dolabrin. Biol. Pharm. Bull. 2001, 24, 299-302. [CrossRef] [PubMed] 
92. Lee, T.B.; Jun, J.H. Can Hinokitiol Kill Cancer Cells? Alternative Therapeutic Anticancer Agent via Autophagy and Apoptosis. Korean J. Clin. Lab. Sci. 2019, 51, 221-234. [CrossRef]

93. Shih, Y.-H.; Chang, K.-W.; Yu, C.-C.; Kao, M.-C.; Chen, M.Y.; Wang, T.-H.; Chi, T.-Y.; Chen, Y.-L.; Shieh, T.-M. Hinokitiol Suppressed Pan-Histone Expression and Cell Growth in Oral Squamous Cell Carcinoma Cells. J. Funct. Foods 2015, 15, 452-463. [CrossRef]

94. Wang, C.-C.; Chen, B.-K.; Chen, P.-H.; Chen, L.-C. Hinokitiol Induces Cell Death and Inhibits Epidermal Growth Factor-Induced Cell Migration and Signaling Pathways in Human Cervical Adenocarcinoma. Taiwan. J. Obstet. Gynecol. 2020, 59, 698-705. [CrossRef] [PubMed]

95. Ouyang, W.-C.; Liao, Y.-W.; Chen, P.-N.; Lu, K.-H.; Yu, C.-C.; Hsieh, P.-L. Hinokitiol Suppresses Cancer Stemness and Oncogenicity in Glioma Stem Cells by Nrf2 Regulation. Cancer Chemother. Pharmacol. 2017, 80, 411-419. [CrossRef] [PubMed]

96. Ido, Y.; Muto, N.; Inada, A.; Kohroki, J.; Mano, M.; Odani, T.; Itoh, N.; Yamamoto, K.; Tanaka, K. Induction of Apoptosis by Hinokitiol, a Potent Iron Chelator, in Teratocarcinoma F9 Cells Is Mediated through the Activation of Caspase-3. Cell Prolif. 1999, 32, 63-73. [CrossRef] [PubMed]

97. Li, J.-Y.; Liu, C.-P.; Shiao, W.-C.; Jayakumar, T.; Li, Y.-S.; Chang, N.-C.; Huang, S.-Y.; Hsieh, C.-Y. Inhibitory Effect of PDGF-BB and Serum-Stimulated Responses in Vascular Smooth Muscle Cell Proliferation by Hinokitiol via up-Regulation of P21 and P53. Arch. Med. Sci. AMS 2018, 14, 579. [CrossRef] [PubMed]

98. Lee, T.-B.; Seo, E.-J.; Lee, J.-Y.; Jun, J.H. Synergistic Anticancer Effects of Curcumin and Hinokitiol on Gefitinib Resistant Non-Small Cell Lung Cancer Cells. Nat. Prod. Commun. 2018, 13, 1934578X1801301223. [CrossRef] 